Moultrie J, Clarkson P J, Probert D R, (2005), A tool to evaluate design performance in SMEs, Submitted to International Journal of Productivity and Performance Measurement, Special edition on Performance in Design and Manufacture, Submitted March 05.

\footnotetext{
Abstract: the creation of well designed products is widely acknowledged as an important contributor to company success. In principle, an effective design process, as part of the wider new product development (npd) process, should result in well designed products. This paper presents a tool to enable a design team to evaluate their design process in a workshop setting, with a view to targeting improvements.

This tool is based on literature and has been iteratively developed using a mixed research approach, including detailed exploratory cases and application in action research mode.

The resulting tool comprises two main components. A 'process audit' based on process maturity principles, which targets the design related activities in npd. The process audit enables a company team to identify improvement opportunities in the design process. A product audit enables perceptions towards product characteristics to be assessed. The audit tool does not seek to be a benchmarking tool, but aims to capture 'good design' principles in a form which is accessible and useful to practitioners.

In use, the tool enabled managers to balance their concern with meeting budget and timescale demands against the importance of producing well designed products. By first focusing on the tangible output of the design process - the product - practitioners are better able to understand the way in which design decisions influence product usability, desirability and producibility. Evidence from cases confirms the value and originality of this tool.

Previous tools addressing product development have focused on strategic and managerial concerns. This novel assessment tool focuses explicitly on design issues, within the wider context of npd.
} 


\section{A TOOL TO EVALUATE DESIGN PERFORMANCE IN SMES}

\section{James MOULTRIE}

Institute for Manufacturing, University of Cambridge, Mill Lane, Cambridge, CB2 1RX, UK jm329@eng.cam.ac.uk

\section{P John CLARKSON}

Head of the Engineering Design Centre, Department of Engineering, University of Cambridge

\section{David PROBERT}

Head of the Centre for Technology Management, Institute for Manufacturing, Department of Engineering, University of Cambridge 


\title{
A TOOL TO EVALUATE DESIGN PERFORMANCE IN SMEs
}

\begin{abstract}
The creation of well designed products is widely acknowledged as an important contributor to company success. In principle, an effective design process, as part of the wider new product development (NPD) process, should result in well designed products. This paper presents a tool to enable a design team to evaluate their design process in a workshop setting, with a view to targeting improvements.
\end{abstract}

\section{Approach}

This tool is based on literature and has been iteratively developed using a mixed research approach, including detailed exploratory cases and application in action research mode.

\section{Findings}

The resulting tool comprises two main components. A 'process audit' based on process maturity principles, which targets the design related activities in NPD. The process audit enables a company team to identify improvement opportunities in the design process. A product audit enables perceptions towards product characteristics to be assessed. The audit tool does not seek to be a benchmarking tool, but aims to capture 'good design' principles in a form which is accessible and useful to practitioners.

\section{Value to practitioners}

In use, the tool enabled managers to balance their concern with meeting budget and timescale demands against the importance of producing well designed products. By first focusing on the tangible output of the design process - the product - practitioners are better able to understand the way in which design decisions influence product usability, desirability and producibility. Evidence from cases confirms the value and originality of this tool.

\section{Value to theory}

Previous tools addressing product development have focused on strategic and managerial concerns. This novel assessment tool focuses explicitly on design issues, within the wider context of NPD.

\section{KEYWORDS}

Design audit tool, design process 


\section{INTRODUCTION}

'Good design' is a significant source of competitive advantage, both in markets with mature products and for highly innovative technologies [Walsh et al 1992, Lorenz 1994, Moultrie et al 2002, Kotler \& Rath 1984]. In a review of 60 small engineering firms, Black \& Baker [1987] determined that those with a strong 'design orientation' also exhibited high growth. Walsh et al [1992] identified a generally positive relationship between 'design consciousness' and commercial success (profit margin). In a follow up study [Roy 1999], it was concluded that growing firms used more external design expertise, had a more positive attitude towards product design and were more innovative. In a survey of 800 UK companies, Sentence [1997] established a positive relationship between business performance (profitability, exports and growth) and design expenditure. Significant empirical evidence supports the view that a strong design capability is important to business success.

However, many SMEs face specific challenges in the design of new products. Many critical design-related activities are often poorly performed in small companies [Huang et al 2002]. Resource limitations and perceived barriers to involving external specialists result in 'silent design' [Gorb \& Dumas 1987] where engineering or marketing staff undertake aesthetic and ergonomic design work themselves [Norman 1998]. This principle can be extended to include other market and user focused elements of the design process; 'silent marketing' [Moultrie et al 2002].

In addition, many New Product Development (NPD) processes emphasise the attainment of managerial objectives such as time to market, project spend, risk reduction and unit cost [Wheelwright \& Clark 1992, Cooper 1993, McGrath 1996]. But, it is still possible for a highly efficient process to result in products which are difficult to use, look terrible and are costly to manufacture. As companies gain better control over selecting and managing projects, attention must focus on the delivery of high quality products. Walsh et al noted that "product design is a crucial but often neglected and misunderstood activity in the performance of firms and economies" [Walsh et al 1992].

This paper describes the development of an audit tool to enable practitioners in SMEs to assess design performance, and take a wider view of the importance of 'good design' issues. Following a brief overview of the research methods, the two components of the audit tool (process audit and product audit) are individually described, followed by a brief summary applying the audit tool in three cases. Wider implications for practice, theory and further work are then discussed. 


\section{METHODS}

This research resulted in a tool for assessing design performance in SMEs, with a view to improving the ultimate outputs of the design process. This ambition was consistent with the general aims of design research which not only aims to develop understanding about the phenomenon of design, but also "to improve the chances of producing a successful product" through the development and validation of design methods [Blessing et al 1995]. Swann notes that "design deals in human interactions with artefacts and situations that contain a great deal of uncertainty. Design research is tied to a domain that derives its creative energy from the ambiguities of an intuitive understanding of phenomena" [Swann 2002]. Accordingly, the design audit tool has been developed iteratively, following an applied research methodology, through four iterative phases of exploration, tool development, tool application and reflection [Eckert et al 2003].

- Phase 1 - exploratory study: literature and exploratory cases confirmed the need for a tool to support improved awareness of good design issues. This exploratory phase included four longitudinal cases to explore design issues throughout the product development cycle, identify good design issues in practice and explore attitudes towards design. The cases were chosen from a shortlist of around 20 companies, based on appropriate company size, culture, sector and location. In each case, the company was an SME, operating in a business to business sector. Data was captured through regular progress meetings, anecdotal observations, project documentation and a semi-structured interview at the end of each project.

- Phase 2 - tool creation and feasibility: a prototype 'process audit' was developed, based upon findings from phase 1 , in addition to further expert input. This first prototype was subjected to a preliminary evaluation; to 'sense-check' its content and construction via six semi-structured interviews with industrialists. This small study confirmed the basic viability of the approach as well as informing the content and structure of the audit; including errors of omission, commission and organisation of information.

Following initial modifications, the tool was then applied in three live cases, following an action research approach [Platts 1993] to establish the feasibility [Canez 2000], usability and utility [Neely 1993] of the tool. After each application, the results were reviewed and modifications were made as appropriate. Multiple data sources were used in each case, including verbal feedback from all participants, structured feedback questionnaires, postworkshop reviews and researcher observation. An additional researcher-observer was also present at each workshop, to provide an independent perspective. 
- Phase 3 - tool development: based on feedback from the feasibility phase, modifications were made to the audit tool and the delivery process. The most significant change was the introduction of the 'product audit' as a pre-cursor to the 'process audit'. The revised audit tool was then applied in a further three companies, again being assessed for feasibility, usability and utility.

- Phase 4 - validation: finally, the audit tool was exposed to a wider audience from ten organisations to validate findings from the development phase. In each case, the respondents were given a copy of the full design audit (in the form of a 'workbook') before being asked to make comments Results from semi-structured interviews and written feedback were incorporated into a final version of the audit tool. A full list of cases is provided in Table 1.

\section{[TABLE 1: Summary of cases ABOUT HERE]}

During this development cycle, the design audit progressed through 3 substantial revisions affecting the underlying architecture of the tool, with over 40 smaller modifications to individual details including activity descriptions, graphical layout and delivery procedure. The research sequence, cases and audit tool revisions are illustrated in figure 1.

\section{[FIGURE 1: Research process and audit tool revisions ABOUT HERE]}

\section{Methodological issues}

Three major methodological concerns were considered during the research; causality, generalisability and the impact of the researcher:

- Influence of the researcher: in the delivery of a tool or procedure, the facilitator may influence outcomes due to their personal knowledge, skills or characteristics. This concern was addressed wherever possible by using different facilitators with varying degrees of expertise. However, as a pseudo-experiment, there were no true control groups against which to evaluate the influence of different researchers, nor was there sufficient time or resources to adopt this approach. Thus, workshop participants were directly requested to consider the influence of the facilitator on the effectiveness of the tool during feedback after interventions. This feedback also served to reduce the potential for researcher bias in interpreting the impact of the tool.

- Direct causality: in the development of a novel tool, it is difficult to attribute any observed effects to the procedural intervention itself [Maslen \& Lewis 1994]. Specifically, it is difficult to assess whether any observed changes are a result of the procedure or the effect of time just thinking about the problem under consideration. Acknowledging this potential 
limitation, feedback on the usefulness and usability of the design audit was generated using a variety of inputs, including structured feedback, researcher observation and postworkshop interviews. These interviews enabled more reflective comments, once the immediate perceptions to a workshop session had passed. Where possible, feedback was also gained from independent observation. Through 'triangulating' these multiple inputs, it was possible to address the issues of causality as far as is reasonably possible.

- Generalisability: accepting that a general goal of research is to develop generaliseable knowledge, then a key limitation of action research methodologies is the necessity to focus on implementation in a small number of companies [Warmington 1980]. It is unlikely that a specific procedure will prove useful in all organisations, and thus it is difficult to generalise the possible effects of a procedure. The design audit has been created to raise awareness of design issues in SMEs and in a sense contains an inbuilt contingency framework. It is not expected or desirable for example that all companies exhibit leading performance in all areas. Different responses to audit questions would be expected in different contexts, including volume of manufacture, company size, company sector or culture. Nonetheless, a potential limitation of this work is that there may be difficulties in demonstrating the external validity or generalisability of the procedure [Gill \& Johnson 1997]. The inclusion of a final validation phase, to gain wider industrial feedback goes some way towards addressing this concern [Scandura \& Williams 2001]. Finally, potential contingent factors were noted during application to identify any significant implications for generalisability; including the size and nature of the firm, the industry sector, technology capabilities and resource availability.

\section{THE PROCESS AUDIT}

As a multi-functional activity, with inherently unpredictable outcomes, New Product Development (NPD) is acknowledged as being risky, difficult and highly complex [Cooper 1993]. Whilst it may be possible to achieve a successful outcome once, through a mixture of luck, perseverance, perspiration and inspiration, it is much more difficult to repeat success again and again. Wheelwright \& Clarke [1992] claim that in order to respond effectively to increasing market, technical and business uncertainties, NPD needs to be clearly structured, rapid and highly productive. It is generally accepted that the likelihood of success is significantly increased if some form of structured process is followed. But, what are the characteristics of a 'good' design process and what might an effective process look like?

The process of product creation is generally described from two perspectives; the design process and the NPD process. Whilst clearly related, there is a subtle difference between the two. Design processes can be applied to all types of creative activity, whether individual, as 
part of a design team or as part of a commercial organisation. In manufacturing businesses, the design process describes a sequence of 'technical activities' and does not (generally) provide any managerial framework; to control risks, to support 'go/no-go' decisions or enable investment analysis [Otto \& Wood 2001]. The focus of the design process is thus on the generation, evaluation and implementation of solutions. In contrast, the NPD process aims to ensure the appropriateness of these solutions to the business. Thus, the design process is subtly different to the NPD process. Otto and Wood [2001] aimed to differentiate between the two:

The NPD process is ... "the entire set of activities required to bring a new concept to a state of market readiness... including everything from the initial inspiring new product vision, to business case analysis activities, marketing efforts, technical engineering design activities, development of manufacturing plans, and the validation of the product design to conform to these plans, through to the development of the distribution channels for marketing and introducing the product."

The design process is ... "the set of technical activities within a product development process that work to meet the marketing and business case vision"

Thus, the 'design process' can be viewed as an essentially technical process. In contrast, the NPD process, emphasises strategic and managerial issues, to ensure that the right type of product is developed and managerial targets are achieved [Bruce et al 1999].

The boundaries between the two are clearly fuzzy and it can be difficult in practice to distinguish design activity from the many other activities that it supports in the NPD process [Nixon 1999]. The distinction however is important in the development of an audit tool which seeks to focus on design issues in an NPD context.

\section{Assessing design process performance}

Process maturity approaches have emerged as an effective way of capturing 'good practice' knowledge in a form which also supports improvement initiatives and have been applied to a variety of business issues [Fraser et al 2002]. Process maturity can be defined as

The degree to which a process/activity is institutionalised and effective [Dooley et al 2001,Paulk et al 1993]. Maturity assessment helps to predict an organisation's ability to meet its goals [Paulk et al 1993] and provides guidance on targeting improvement [Chiesa et al 1996] by describing the progression of performance through incremental stages of development.

There are two general approaches to developing maturity based assessment tools; Maturity grids and Capability Maturity Models. 
Maturity Grids aim to communicate a few basic principles in a simple but effective way [Crosby 1979]. For a given activity, typical levels of behaviour exhibited at different maturity levels are described. The grid aims to codify what might be regarded as good (and bad) practice along with a number of intermediate or transitional stages. There is generally no attempt to prioritise one activity over another, or to aggregate scores into an overall maturity rating. Several grid based audit tools have been developed for assessing various aspects of product development:

- Product \& cycle time excellence [McGrath et al 1996]: NPD process audit with 7 elements described at 4 maturity levels. The tool emphasises project management and project generation issues.

- $R \& D$ Effectiveness audit [Szakonyi 1994]: consisting of 10 'R\&D' activities described over 6 'maturity' levels using insights from industry.

- Project management audit [Ibbs \& Kwak 2000]: consisting of 148 multiple choice questions covering eight knowledge areas and six project phases.

- Technical innovation audit [Chiesa et al 1996]: addressing the "managerial processes and organisational mechanisms through which innovation is performed" and comprising 22 sub-processes described across 4 (undefined) maturity levels.

Capability Maturity Models (CMM) were initially developed to support software development [Paulk et al 1993] offering a more detailed approach. CMMs benefit from completeness, but at the expense of accessibility and succinctness. A number product development audit tools based on CMM principles have been produced. These include tools for assessing product usability [Earthy 1999], continuous NPD improvement [Caffyn 1997] and project management [Dooley 2001].

The maturity grid approach provides an accessible way of capturing 'good practice' issues as part of a framework for improving performance. Existing audit tools focus primarily on managerial concerns and none of them specifically address product design related issues.

\section{New Product Development (NPD) success factors}

In much NPD research, there is an implicit assumption that an effective product development process will lead to a strong product. With this in mind, a number of empirical studies have aimed to establish the factors which will increase the likelihood of success or reduce the chances of failure. Following some early exploratory studies [Lazo 1965, Booz et al 1968], Myers and Marquis [1969] studied 567 projects in 120 firms, measuring project success financially. In 1974, Rothwell et al carried out the first dyadic comparison between successful and unsuccessful projects [1974]. There have since been a number of further success factor 
studies [including Utterback et al 1976, Cooper 1979, Cooper 1984, Ledwith 1999, Maidique \& Zirger 1984].

In addition, there have been several attempts to collate findings from previous studies, to establish common success factors [e.g. Utterback 1976, Barclay 1992, Montoya-Weiss \& Calantone 1994, Ransley \& Rodgers 1994, Griffin 1997, Lilien \& Yoon 1989, Balbontin et al 1999, Ernst 2002, Brown et al 2003]. These meta-analyses are useful in highlighting the different approaches to clustering success factors based on the perspective and interests of the researchers.

To inform the audit tool, outputs from 47 such success factor studies were reviewed to establish the recurring themes. Dominant factors include cross functional involvement, and user understanding. Top management support is frequently cited as a success criteria, although in many SMEs the senior managers are arguably excessively involved [Dickson et al 1995]. Collectively, these factors emphasise the importance of managing the process as the key to success. Some early stage design issues are prominent, but the remainder of the design process is only rarely mentioned. Factors relating to 'good design' are only evident in the apparent importance of strong product differentiation and unique product features. However, whilst it may be obvious that clear differentiation is a vital ingredient of competitive success, there is little attempt to identify which aspects of the design mix are appropriate in generating uniqueness or differentiation in different contexts.

\section{Design processes activities}

To address the managerial bias of NPD success factor studies, activities represented in design processes were also reviewed. Interestingly, there have been no success factor studies explicitly aimed at the design process.

Representations of the design process can be classified as either descriptive or prescriptive [Cross 1998]. 'Solution focused' descriptive models suggest the early proposal of a 'straw man' solution for subsequent evaluation, refinement, development or abandonment. In contrast, prescriptive representations tend to be 'problem focused' and are often based on views of 'good practice', providing a highly detailed and systematic sequence of activities, for the practitioner to follow if desired [Cross 1998, Pugh 1996, Pahl \& Beitz 1996]. Prescriptive models tend to be represented as a linear progression, sometimes with feedback loops or overlapping stages to indicate iteration [Cross 1998, Pugh 1996].

While there is no overall agreement on a specific instantiation of the design process, it is possible to establish some common elements. Eight well established 'design' processes [including Otto \& Wood 2001, Cross 1998, Pahl \& Beitz 1996, Urban \& Hauser 1993, Ulrich 
\& Eppinger 2000] were compared, to identify recurring activities as a key input into the development of the audit tool.

In general, the NPD and Design communities place most importance on pre-development activities, including the need for strong market and customer intelligence. There is less focus in the NPD domain on issues such as prototyping and creativity. Within the 'design' domain however, there is very little consideration of project management issues, such as the generation of a 'business case' or the need for project authorisation.

\section{The process audit}

Based on literature and findings from cases, a process audit tool was iteratively developed, constructed in the form of a maturity grid [Crosby 1979] of 24 Key Design Activities. During development, the audit tool went through a number of major and minor revisions. The final audit tool comprises 10 management related activities and 14 design related ones was found to be usable, useful and complete.

The process audit classifies performance against 4 maturity levels, with 5 key ingredients to each level: benefits perceived in the activity, people involved, timing, the degree to which the activity is formalized and the level of expertise. This structured approach helped to ensure consistency in description of performance across activities.

The process audit is presented in two forms; summary grids and detailed grids [Fraser et al 2001]. The summary grid captures the performance of each activity in a simple statement, designed to be succinct and to the point. The detailed grids expand on this heading to provide a richer description, based around the elements of maturity. An example summary grid is illustrated in Figure 2. An example detailed grid is illustrated in Figure 3. Summary grids for the whole audit tool are included in Appendix 1.

[FIGURE 2: Example summary grid of process audit for 'requirements capture' ABOUT

\section{HERE]}

\section{[FIGURE 3: Example detailed grid of process audit for 'market segmentation' ABOUT HERE]}

The process audit has been designed for use in a workshop setting, taking about half a day, with representatives from a variety of functional groups. Workshop participants are first introduced to the range of activities and asked to identify any which in their view might be missing. Participants are then asked to score current performance and identify opportunities for improvement. Various strategies for scoring current performance have been tried. In early applications, individual participants scored each activity alone, and later collated responses to identify activities for further discussion. This approach is effective in highlighting differences 
in opinion, but can also be divisive. In later applications, participants have been split into subgroups to discuss each activity, using the summary and detailed grids to agree scores for both current performance and desired future performance. These sub-groups then share views and discuss alternative priorities. This approach has proved more useful in generating practical outputs. The workshop culminates with the capturing and prioritisation of actions for improving the design process.

\section{THE PRODUCT AUDIT}

Several of the NPD success factor studies cited product related factors as contributing to success. Utterback et al [1976] noted that a product must have "advantage over the competition in a key aspect and moderate advantage in several aspects". Other product factors include technical superiority [Booz et al 1968, Balbontin et al 1999], clear benefits [Ernst 2002] and product uniqueness or novelty [Cooper 1984, Page 1993, Mishra et al 1999]. Surprisingly however, product appeal, ease of manufacture, aesthetics and ergonomics are not noted, as it is through these characteristics that differentiation and superiority are achieved. Lorenz [1994] argued that conventional means of differentiation (cost and quality) are now 'entry tickets' and that product appearance and character are now the key to producing meaningful differentiation. Nixon [1999] specifically mentions that the relative importance of product aesthetics as a primary differentiator in crowded market segments. Most insightfully, Rutter \& Agne [1998] conducted a survey of 80 consumers to explore attitudes towards 'good design' and concluded that customers seek products which 'look good and work well'.

Given the lack of academic consensus over the attributes of a well designed product, the judging criteria of 17 major international design awards were reviewed. Awards included: the Australian design awards, German Red Dot awards, Japan G mark, German IF design awards, Italian Golden Compass awards, Korean Good design award and the IDEA design awards in the USA.). Different judgment criteria were clustered to identify common themes. In order of frequency of occurrence, the dominant judgment criteria are: Usefulness, Ergonomics, Novelty, Aesthetics, Technical and engineering quality and product economics. Literature exploring each of these characteristics in detail was reviewed to establish the underpinning content of the product audit.

\section{The product audit}

Based on literature and case evidence, a product audit tool was iteratively developed, which captures elements of 'good design' from a product perspective. The product audit has 7 main components as described below. These were chosen to reflect the different levels of the 'design mix' [Kotler et al 1996] and to reflect the dominant themes of the major international design awards. 
- Core benefits: A brief assessment of the underlying need for the product, its degree of functionality, the availability of alternative solutions and its perceived value in the marketplace [Cagan \& Vogel 2002, Harkins 1994].

- Engineering quality: Capturing the degree to which performance meets expectations, perceived reliability, build quality and product durability [Hertenstein 2001, Walsh 1992].

- Product usability: Assessing the ease with which a user can begin using a product, its ability to be maintained and cleaned, the clarity of the interface (cognitive usability) and its physical usability (size, shape and forces) [March 1994, Jordan 2000].

- Product desirability: Considering issues of visual clarity, visual order, sense and harmony, the product's symbolic value and the emotional responses delivered [Crilly et al 2004]. An example worksheet is illustrated in Figure 4.

- Product producibility: Addressing component manufacture, assembly and test and platform / modularity concerns [Bralla 1998, Galsworth 1994, Meyer \& Lehnard 1997].

- Product profitability: Enabling the assessment of revenue, production costs, selling and support costs, profit and market share compared to expectations.

- Product novelty and differentiation: Enabling the assessment of each element of the 'design mix' for novelty and to establish the key product differentiators [Utterback 1976, Mishra et al 1999].

\section{[FIGURE 4: example product audit worksheet - product desirability ABOUT HERE]}

The product audit enables a largely subjective assessment of perceptions towards the object. Semantic difference scales provide an appropriate way of capturing perceptions towards products, by providing two opposing descriptions of key characteristics. This approach also has the benefit of enabling key 'good design' issues to be captured, both in the choice of characteristics and in the description of the opposing scales.

When used in a workshop setting, it has been found to be beneficial to compare and contrast two dissimilar products. This helps provide a baseline score against which the company's own product can be compared and improves objectivity. A typical product audit workshop takes around half a day, involving a multi-functional team.

There are 3 ways in which the results of the product audit are captured. Firstly, perceptions of current performance are mapped against perceived customer importance. Secondly, product strengths and weaknesses are captured and finally, proposed design improvements are captured. The full product audit is illustrated in Appendix 2. 


\section{SELECTED CASE EXAMPLES}

The design audit has been applied in a range of industrial settings, as outlined in the methods section. Early applications centred on the process audit. Later applications also introduced and developed the product audit. The three cases briefly outlined below, are taken from different stages of the audit tool development.

\section{Case M: Security Electronics}

Company $\mathrm{M}$ was a leading producer of electronic test equipment for use in security markets. Established in 1978, the company was growing and employed around 50 people with a turnover of approximately $£ 3 \mathrm{~m}$. The company had traditionally competed in a niche market through technical innovation and technology leadership. However, as the market has matured, competitive pressures were raising the importance of ergonomic and stylistic issues. The company was located on a single site, and undertook most design, development and production activities in-house. Their only previous experience of using industrial design was unsuccessful, with the results not justifying the expenditure.

Initial contact with company $\mathrm{M}$ was made at a 1 day design seminar, at which they expressed interest in the design audit approach. With senior management approval, a design audit workshop was carried out, involving ten people from across the business. As a result, two subsequent training sessions were held, focusing on market/user understanding and the product specification. In addition to these formal engagements, occasional meetings were held to maintain contact, review progress and gain feedback. Finally, a year after the initial meeting, a formal wrap-up session was held to establish opinions on the longer term impact of the design audit.

Company feedback was generally positive, with favourable comments on utility, usability and feasibility. The design audit appeared to offer genuine practical benefits. The company team identified several opportunities for improving their design process and undertook subsequent training as a result. They viewed the content, structure and presentation of the tool to be appropriate, with no obvious errors of omission or commission. Improved teamwork and communication were nominated as the major improvements as a result of the design audit. There was some evidence of product improvement with the release of a new product with improved aesthetics and ergonomics, although direct causality was difficult to prove. There was also longer term evidence of improvement, including the appointment of a marketing coordinator to support product development and improved cross functional communication.

The process audit satisfied the tests of usability and feasibility, although there was a sense that the procedure was potentially repetitive. Alternative key design activities were also suggested. 
The audit satisfied the company objectives to improve communication and help formalise the NPD process.

\section{Case N: Medical lasers}

Company N was relatively young, founded in 1991 pioneering the use of diode lasers for medical applications. Over 12 years, the company had grown substantially, through the launch of new products and acquisition of complementary companies. Company $\mathrm{N}$ had a head office in the USA, with a research and development facility in the UK. This local facility had a turnover of around $£ 6 \mathrm{~m}$ and employed roughly 70 staff. The company incorporated its proprietary laser technology into a number of clinical products, which in turn addressed a growing market for non-invasive treatments for many ailments, from cancer to dermatology. As technology leaders, the company's products were differentiated through performance and service provision. However, whilst entry barriers were high, new entrants were challenging the company's market leading position. Thus, the company was beginning to consider other ways of differentiating its products.

The Engineering Director expressed interest in the design audit following a presentation at an evening workshop. He believed that the audit approach would help him gain cross functional support for improvements to the company's product design process. As a relative newcomer to the company, he wished to increase the formality of the process, but with grass-roots consensus for these changes. Following two meetings with the senior management team, a design audit workshop was planned.

A design audit workshop lasting half a day was held, with ten participants. Before the workshop, participants had been asked to assess the design process and a product, using a slimmed down version of the product and process audit tools. Responses were reviewed, before investigating several activities in more depth. The product audit highlighted weaknesses in design for manufacture, which was later confirmed following the process audit. The team also identified opportunities for improving user understanding.

Feedback from the participants was mixed. The overall process was felt to be valuable, but the assessment process was judged to be tedious. The inclusion of additional key design activities had detrimentally affected the usability of the tool. However, the product audit had been effective. Improvements were needed to the delivery procedure and several elements of the process audit required changes to improve clarity.

\section{Case P: Agricultural machinery}

Company $\mathrm{P}$ has existed for over 30 years, and has an annual turnover of around $£ 9 \mathrm{~m}$, employing approximately 130 staff. Roughly ten percent of the workforce was involved in the generation of new products and customising standard products to meet specific customer 
needs. The company had been owned and managed by the founding family throughout the 30 years. The company began by developing novel machinery for farmers and has gradually expanded its product range, to produce and install systems for sorting, cleaning and packing root crops; including potatoes, carrots, onions and parsnips. In this specialised market, the company competed by offering leading technical features and delivering reliable machinery at a competitive price. In addition, they provided customers with a full after sales offering.

The newly appointed engineering director (son of the company founder) became interested in the design audit with a view to increasing the competitiveness of their products and improving the new product design process. Although technically leading, their product range was beginning to suffer from new market entrants, and as a result had falling gross margins.

Following an initial meeting with senior management to clarify objectives, the complete design audit was applied over two workshops, each lasting a whole day. Both workshops were attended by 10 members of staff representing all facets of the business. In the first workshop, the cross functional team assessed a current product to establish strengths and weaknesses, potential improvements and key differentiators. Product producibility and usability were both identified as priorities for improvement. Outputs from this stage informed the process audit, which targeted design for manufacture, user involvement and product specifications as key areas for improvement. The delivery of the process audit was revised, to combine both summary and detailed grids. This reduced repetition and improved overall understanding.

As a result of both workshops, the company revised its product development process, to address the issues raised. The company also implemented several design changes to the product under assessment; addressing aspects of benefit to both the company and their customers.

Feedback was extremely positive, with utility, usability and feasibility all scoring highly. The audit tool successfully raised awareness of good design issues and encouraged the participants to take tangible action. Both the product and process audits were judged as useful, although the product audit was marginally preferred.

The management team was delighted with the outputs of the workshop series and further training in design for manufacture for low volume manufacture was requested.

\section{DISCUSSION}

Through a process of application, review and modification, a robust model of 'good design' in the form of a design audit tool has been developed capturing both product and process perspectives (Figure 5).

[FIGURE 5: Structure of the design audit - product and process ABOUT HERE] 
Initially, the 'process audit' aimed to encourage a more holistic approach to design to (in the long run) create better-designed products. This process based view helped raise general awareness of design issues, but failed to have a significant impact on the actual design of products. Case companies remained pre-occupied with perennial managerial issues, such as teamwork and communication. In later applications, by first assessing the design of an existing product, discussions on the design process then became more useful.

The process maturity approach enables an assessment of current performance and also indicates opportunities for possible improvement through the codification of 'good' and 'not so good' practices, derived from literature and case studies. The maturity grid is able to capture a range of practice, described in language which is familiar to the practitioner. In contrast, yes/no checklists offer a binary response to a good practice statement and Likert-scale questionnaires only provide description of performance at the extremes. It was assumed that the increased granularity and precision of the maturity grid would result in a high degree of consensus between different respondents. However, despite fairly precise descriptions of performance at each level of the process audit, individuals in companies still have greatly differing opinions over current performance. This highlights the inherent unreliability of any single respondent assessment and demonstrates the value of the tool in generating discussion and raising awareness. It also indicates that the tool would be inappropriate for benchmarking performance between companies.

The product audit draws on a wide array of sources, including product aesthetics, design for manufacture, and ergonomics. Due to space limitations, these are not expanded upon here. The product audit has proven successful in encouraging a more user centred view of product design. Before using the product audit, good design is often viewed parochially in terms of profitability or producibility. By taking a more structured view, with an emphasis on customer perceptions, greater emphasis is given to the softer elements of the design mix, such as aesthetics and ergonomics.

\section{Implications for practice}

Companies must continually introduce new products to market, to remain profitable in the face of competitive activity and technological change. Effective products should improve the satisfaction of consumers and users, whilst also resulting in improved business performance. There is both anecdotal and empirical evidence of the value of good design. However, many small companies face specific challenges in the design of new products, often resulting in technically adept products which are either difficult to use or are not desirable to the target audience. Conversely, an attractive product may be let down by poor design for manufacture or weak technical performance. These product deficiencies are indicative of a lack of awareness of the importance of good design and the limited adoption of good design practices. 
Recognising these issues, the design audit has aimed to capture key aspects of the design process which are essential and are often underperformed. The complete product and process audit thus provides practitioners with a simple way of understanding current capability and mapping actions for possible improvement. Specifically, the audit tool aims to balance the need to consider managerial concerns against the importance of good design, the key design activities and the characteristics of well-designed products. Before application of the design audit, there was no evidence of structured reflection or evaluation of design performance in any of the case companies. Where firms did evaluate performance, it was solely against time/spend targets. There was little evaluation of how well design work was being performed.

Throughout this research, a range of small-companies were involved, largely from the industrial goods sector. In additional to the creation of the design audit, these various engagements resulted in a number of general impressions about the way in which product design is executed and managed. Whilst these cannot be described as concrete findings, they do however provide some interesting insights which might inform possible future research and are described briefly below:

- Silent marketing: Almost without exception, 'inbound' marketing activities (e.g. market research, competitive analysis etc.) were poorly performed. The marketing staff (when there were any at all) were typically acting as 'sales support' engaging in 'outbound' marketing activities (advertising, PR, technical sales etc). As a result, there was an overreliance on managerial gut-feel, occasionally calibrated by experience in the industry. Where market analysis was carried out, it was generally performed by people with little experience or skill in that area ('silent marketing') and in several companies, the marketing personnel had been promoted from administrative roles.

- Insufficient user/customer involvement: Closely related with underperformance in marketing activities was the general reluctance to actively involve users (or customers) in product creation. Efforts to really understand the motivations of users were often halfhearted, and served to provide justification to decisions already made. Several companies expressed reservations in involving customers to assess original concepts due to concerns over intellectual property and commercial confidence. However, this fear was often misguided as rapid competitive response was in most cases unlikely and the benefits of user feedback far outweighed any potential risks.

- Limited resources: The limited resources available to the companies meant that they were unable to simultaneously develop a portfolio of high risk, medium risk and safe projects as would be recommended in traditional R\&D management texts. Furthermore, SMEs do not have the luxury of developing new technology 'off-line' to be later incorporated into new 
products. As a result, they erred towards the safer projects, which were typically incremental developments of existing offerings. Furthermore, it was apparent that the product development process generally prevented the riskier projects by presenting hurdles which could not easily be overcome.

- Organisational turbulence: Constant changes in company ownership, senior management structure, location and financing arguably had a far greater influence on product development than external factors (such as competitive activity). This was especially evident in the companies which had undergone significant organisational change. With each change, the priorities were reassessed, the strategy changed and the flow of new products was disturbed. As a result, the need for each new project to succeed increased and the desire to take on risks correspondingly reduced.

- Poor design for manufacture: Although the basic design for manufacture principles are well established, there was little evidence of any formal design for manufacture and even less proactive product platform planning. This was manifest by the general reluctance of the development teams to estimate the likely unit cost of a new product.

- Changing role of industrial design: Most of the companies were (perhaps justifiably) wary of the expense of external industrial designers. Few of the companies were aware of the sophistication of many of the design firms and their ability to deliver far more than a 'pretty box', including comprehensive engineering services and thorough user and market research. These external skills potentially offer many small companies the opportunity to enter new markets and develop more radical products than their internal resources would be capable of.

- Quality to market: Finally, several managers had clearly been influenced by some of the high profile product development research findings; notably, the time-to-market perspective. It was apparent in several companies that time (and to a lesser extent spend) were not the critical factors. Almost without exception, the more important requirement was the need to deliver high quality products to market. However, in several cases, managerial attention on 'stages' and 'gates' resulted in less focus on the design itself, with the knock-on effect of expensive re-work and poor market response.

\section{Implications for theory}

Two perspectives have largely dominated research in new product development; 'success factors' studies [e.g. Rothwell et al 1974, Montoya-Weiss \& Calantone 1994] and 'stage-gate' style processes [e.g. Cooper 1993]. Both of these perspectives reinforce the prevailing wisdom that 'success' is a function of an effective new product development process. Moreover, there is an implication that it is the management of this process which is critical. Whilst these ideas 
have made a substantial contribution to the understanding and practice of product development, there is also evidence that they are insufficient.

The outputs of many NPD success factor studies seem to suggest that a well managed process is the key route to success. The need for that process to deliver exceptional products is often overlooked. Several studies identify 'product superiority' [Montoya-Weiss \& Calantone 1994, Ernst 2002] as a key factor, which is in many ways somewhat tautological. To be truly useful to practitioners, some sense of how this superiority is to be achieved is essential. There is thus an opportunity for new product development success factors to be derived from a product as well as a process perspective. There is also some evidence that the factors quoted are incomplete. Many empirical studies for example have confirmed the positive relationship between a design orientation and commercial success [Hertenstein 2001]. Others have more specifically identified industrial design as a key contributor [Gemser 2001]. In addition, the environment in which innovative activity occurs may influence team work [Lewis \& Moultrie 2005]. However, these elements are overlooked in almost all NPD success factor studies.

By emphasising the importance of managing the product development process, the need for that process to deliver exceptional products is often overlooked. It is evident from the exploratory cases and from the application of the audit tool that to develop excellent products, there also needs to be sufficient emphasis on the design process. Management controls, checks and measures need to be complemented by high quality 'design thinking'. Product development research needs to be more explicit in distinguishing between these interdependent, but essentially different elements. By making this distinction explicit, NPD research could reflect practice more accurately and provide greater benefit to practitioners by offering a more comprehensive approach.

Even though NPD has been studied for almost half a century, many of the lessons are only gradually being adopted in practice [Cooper 1999], especially in SMEs [Brown et al 2003]. In 1992, Barclay [1992] surveyed around 149 companies and concluded that only 7\% of managers were familiar with the results from the major academic studies. Even when managers are aware, changing product development practices can be challenging when inhibited by ingrained stereotypical behaviour and training [Karlsson 1996]. Success factor studies however are only the tip of the iceberg of the body 'good practice' literature. Much of this literature is functionally biased and is (relatively) inaccessible to practicing industrialists. Maturity approaches to assessing process capability provide a way of capturing such good practice principles in an accessible form which leads to action for improvement. A number of maturity based tools have been devised for product development issues. However, existing approaches have focused largely on managerial concerns. Thus, this research sought to 
develop a design audit tool to capture these good practice issues in a form accessible to industrialists.

\section{Research limitations \& further work}

A key strength of the final audit tool is its comprehensiveness, covering a wide range of design issues. It does not seek to cover these individual issues with great depth $-\mathrm{a}$ whole research programme for example could have addressed the generation of just a product usability audit. The goal was to produce a usable tool, which meant that a number of difficult judgements had to be made about which activities should be included and which omitted. Whilst it would be possible to criticise the tool for errors of omission, the depth and content of the final audit tool are consistent with the aims of the research; to capture good practice issues in a form accessible to industrialists.

Process based research approaches aim to result in an empirically supported tool or process for use in a practical context. This tool should comprise an underlying model of the phenomenon under consideration, combining concepts, categories, overall architecture and where appropriate relationships between elements [Blessing et al 1995, Platts 1993]. The model is then embodied in the tool itself, which seeks to satisfy the desired practical outcomes [Platts 1993, Blessing et al 1995]. The tool is delivered through a process, including the sequence of events, guidance on facilitation and supporting materials [Platts 1993]. In practice of course, there is likely to be an intimate relationship between the model, the tool and its delivery process and variation in one will potentially impact the other. This co-development is hinted at by Platts [1993] who recognises that in application the procedure will be refined and developed. In the context of this research, the design audit tool can be viewed in itself as the vehicle to capture 'good design' issues. Thus, the model of 'good design' is captured in the audit tool's architecture, organisation, concepts and delivery process. Whilst literature and exploratory cases informed the generation of an initial prototype, this changed through iterative application, reflection and modification. Thus, industrial application provided feedback not only about the process, but also about the underlying theoretical concepts.

However, it is important to acknowledge the role of the delivery process on the effectiveness of the audit tool. Clearly the skills and knowledge of the facilitator can have a substantial impact on an engagement. Furthermore, the nature of applied research demands a careful trade-off between the ideal control of variables and the pragmatic need to adapt to the demands of the case companies. For example, different approaches to 'warming-up' the group, establishing goals, scoring worksheets, collating scores and agreeing actions can all be influential. It would however have been difficult - and indeed undesirable - to control the delivery process too rigidly as that would have limited the opportunities for the evolution and improvement of the process between engagements. Nevertheless every effort was made to 
manage, observe, capture and reflect upon the dynamics of each engagement. This learning about the dynamics of delivery was incorporated into the practical recommendations in the final audit tool. These limitations are characteristic of action research and efforts were made to mitigate any potential sources of error as described earlier. However, the impact of delivery in the development and application of an assessment tool could form the basis of worthwhile future research addressing similar themes.

A major challenge in developing a generic audit tool is the reality that a 'one size fits all' solution fundamentally ignores the idiosyncrasies of real companies. The design audit aims to include its own in-built contingencies. A company is given the opportunity to prioritise and assess the importance of each element. However, further work could explore the use of the audit tool across alternative sectors.

\section{CONCLUSIONS}

A design audit had been described which encourages attention to be focused on the achievement of well designed products. The combined product and process view produces a balanced consideration of 'good design' issues to complement more traditional project objectives (cost, time and spend).

By drawing together information from a diverse range of sources, this study hopes to raise practitioner awareness of good design issues and provides a useful and usable tool to support managers in improving both products and the design process that delivers them.

\section{ACKNOWLEDGEMENTS}

This research is supported by the Monument Trust. The author is also grateful to Pete Fraser and Pete Caldwell for their input.

\section{REFERENCES}

[1] Balbontin A, Yazdani B, Cooper R, Souder W, (1999), New product development success factors in american and british firms, International Journal of Technology Management, Vol. 17 No. 3, p259

[2] Barclay I, (1992), The new product development process: past evidence and future practical application part 1, R\&D Management, Vol. 22 No. 3, p255

[3] Black C D, Baker M J, (1987), Success through design, Design Studies, Vol. 8 No. 4, p207-216

[4] Blessing L, Chakrabarti A, Wallace K, (1995), A design research methodology, International Conference of Engineering Design, Praha, 22-24 August

[5] Booz, Allen and Hamilton, (1968), Management of new products, Booz Allen and Hamilton, New York

[6] Bralla J, (1998), Design for manufacturability handbook 2nd edition, McGraw Hill

[7] Brown K, Schmied H, Tarondeau J-C, (2003), Success factors in R\&D: a meta analysis of the empirical literature and derived implications for design management, Design Management Journal, Academic Review, Vol. 2

[8] Bruce M, Cooper R, Vazquez D, (1999), Effective design management for small businesses, Design Studies, Vol. 20 No. 3, p297 
[9] Caffyn S, (1997), Extending continuous improvement to the new product development process, R\&D Management, Vol. 27 No. 3

[10] Cagan J, Vogel C M, (2002), Creating breakthrough products: innovation from product planning to program approval, Prentice Hall, Upper Saddle River, New Jersey

[11] Canez L, (2000), Industrial make or buy decisions: developing a framework and practical process, $\mathrm{PhD}$ Dissertation, University of Cambridge, Department of Engineering

[12] Chiesa, V., Coughlan, P. and Voss, C. (1996) Development of a technical innovation audit, Journal of Product Innovation Management, 13(2): 105-136

[13] Cooper R G, (1979), Identifying industrial new products success: project NewProd, Industrial Marketing Management, Vol. 8 No. 2, p124

[14] Cooper R G, (1984), How new product strategies impact on performance, Journal of Product Innovation Management, Vol. 1 No. 1, p5

[15] Cooper R G, (1993), Winning at new products: accelerating the process from idea to launch, 2nd edition, Perseus Books

[16] Cooper R G, (1999), "From Experience: The Invisible Success Factors in Product Innovation", Journal of Product Innovation Management, 16: 115-133

[17] Crilly N, Moultrie J, Clarkson P J, (2004), Seeing things: consumer response to the visual domain in product design, Design Studies, Vol. 25 No. 66, pp547-577

[18] Crosby P B, (1979), Quality is Free, New York:McGraw-Hill

[19] Cross N, (1998), Engineering Design Methods - Strategies for Product Design, John Wiley \& Sons, England

[20] Dickson P, Schneier W, Lawrence P, Hytry R, (1995), Managing design in small high growth companies, Journal of Product Innovation Management, Vol. 12 No. 5

[21] Dooley, K., Subra, A. and Anderson, J. (2001) Maturity and its Impact on New Product Development Project Performance, Research in Engineering Design, 13:23-29

[22] Earthy J, (1999), Usability maturity model: processes, Version 2.2, Lloyds Register

[23] Eckert C M, Clarkson P J, Stacey M K, (2003), The spiral of applied design research: a methodological view on integrated design research, International Conference on Engineering Design, Stockholm, 2003

[24] Ernst H, (2002), Success factors of new product development: a review of the empirical literature, International Journal of Management Reviews, Vol. 4 No. 1, pp1-40

[25] Fraser P., Moultrie, J. and Holdway, R. (2001) Exploratory studies of a proposed Design Maturity Model, Proc. 8th International Product Development Management Conference, University of Twente, Holland, 11-12 June 2001

[26] Fraser P, Moultrie J, Gregory M, (2002), The use of maturity models/grids as a tool in assessing product development capability, IEEE International Engineering Management Conference IEMC, Cambridge, 19-20 August 2002

[27] Galsworth, (1994), Smart Simple Design - Using Variety Effectiveness To Reduce Total Cost And Maximise Customer Selection, Oliver Wright Publications, USA

[28] Gemser G, (2001), How integrating ID into the NPD process impacts on company performance, Journal of Product Innovation Management, January

[29] Gill J, Johnson P, (1997), Research methods for managers, Paul Chapman Publishing, London

[30] Gorb P, Dumas A, (1987), Silent design, Design Studies, Vol. 8 No. 3, July, p150-156

[31] Griffin A, (1997), PDMA Research on new product development practices: updating trends and benchmarking best practice, Journal of Product Innovation Management, Vol. 14, p429

[32] Harkins J, (1994), Is design doing its job, Machine Design, February 7th, p53

[33] Hertenstein J H, Platt M B, Brown D R, (2001), Valuing design: enhancing corporate performance through design effectiveness, Design Management Journal, Summer

[34] Huang X, Soutar G N, Brown A, (2002), New product development processes in small and medium sized enterprises: some Australian evidence, Journal of Small Business Management, Vol. 40 No. 1, pp 27-42

[35] Ibbs Y H, Kwak C W, (2000), Calculating project managements return on investment, Project Management Journal, June, p38

[36] Jordan P W, (2000), Designing pleasurable products: an introduction to the new human factors), Taylor \& Francis, London 
[37] Karlsson, C. and Ahlstrom, P. The Difficult Path to Lean Product Development, Journal of Product Innovation Management, 13: 283-295 (1996)

[38] Kotler P, Armstrong G, Saunders J, Wong V, (1996), Principles of marketing: the European edition, Prentice Hall, UK

[39] Kotler P, Rath G A, (1984), Design: A powerful but neglected strategic tool, Journal of Business Strategy, Vol. 5 No. 2, p16

[40] Lazo H, (1965), Finding a key to success in new product failures, Industrial Marketing, No 50, Nov, p74

[41] Ledwith A, (1999), New product development in small electronic firms, 7th Annual International High-Technology Small Firms Conference, Manchester Business School, UK, May 1999

[42] Lewis M, Moultrie J, (2005), The organisational innovation laboratory, Creativity and Innovation Management, Vol. 14 No. 1

[43] Lilien G, Yoon E, (1989), Determinants of new industrial product performance: a strategic reexamination of the empirical literature, IEE Transactions in Engineering Management, Vol. 36 No. $1, \mathrm{p} 3$

[44] Lorenz C, (1994), Harnessing design as a strategic resource, Long Range Planning, Vol. 27 No. 5, p73-84

[45] Maidique M A, Zirger B J, (1984), A study of success and failure in product innovation: the case of the US electronics industry, IEEE Transactions in Engineering Management, Vol. 31 No. 4, p192

[46] March A, (1994), Usability: the new dimensions, Harvard Business Review, September-October

[47] Maslen R, Lewis M A, (1994), Procedural action research, Working paper No 1, Institute for Manufacturing, University of Cambridge

[48] McGrath, Michael E. (ed) (1996) Setting the PACE in Product Development: a guide to product and cycle-time excellence. Butterworth-Heinemann

[49] Meyer M H, Lehnard A P, (1997), The Power of Product Platforms - Building Value and Cost Leadership, The Free Press, New York

[50] Mishra S, Dongwook K, Dae H L, (1999), Factors affecting new product success: cross country comparisons, Journal of Product Innovation Management, Vol. 13, No. 6, pp530-550

[51] Montoya-Weiss M, Calantone R, (1994), Determinants of new product performance, Journal of Product Innovation Management, Vol. 11, p397

[52] Moultrie J, Fraser P, Clarkson P J, (2002), The innovation-styling spectrum: a framework for the valuation of industrial design involvement in new product introduction, 9th International Product Development Management Conference, Ecoles de Mines, Sophia Antipolis, 27-28 May 2002

[53] Myers S, Marquiss D G, (1969), Successful industrial innovations, (NSF 69-17), Washington DC: National Science Foundation

[54] Neely A, (1993) 'Production/operations management: research process and content during the 1980s’, International Journal of Operations Management, Vol. 13 No.1, pp5-18

[55] Nixon B, (1999), Evaluating design performance, International Journal of Technology Management, Vol 17 issue 7, p814

[56] Norman D A, (1998), The design of everyday things, MIT Press, USA

[57] Otto K, Wood K, (2001), Product design: techniques in reverse engineering and new product development, Prentice Hall, USA

[58] Page A L, (1993), Assessing new product development practices and performance: establishing crucial norms, Journal of Product Innovation Management, Vol. 10 No. 4, p273

[59] Pahl G, Beitz W, (1996), Engineering design: a systematic approach, Second edition, SpringerVerlag, Berlin

[60] Paulk M.C., Curtis B., Chrissis M.B. and Weber, C.V. Capability Maturity Model SM for Software, Version 1.1, Technical Report CMU/SEI-93-TR-024 ESC-TR-93-177, February 1993

[61] Platts, (1993), A process approach to researching manufacturing strategy, International Journal of Operations Management, Vol. 13 No. 8, p4-17

[62] Pugh S, (1996), Creating innovative products using total design: the living legacy of Stuart Pugh, Addison-Wesley Publishing, USA

[63] Ransley D, Rogers J, (1994), A consensus on best R\&D practices, Research Technology Management, March-April 
[64] Rothwell R, Freeman C, Horsley A, Jervis V, Robertson A, Townsend J, (1974), The hungarian sappho: some comments and comparisons, Research Policy, No 3, p30

[65] Roy R, (1999), The long term benefits of investing in NPD by SMEs, New Product Development \& Innovation Management, December 1999, p281

[66] Rutter B G, Agne J A W, (1998), A Darwinian theory of good design, Design Management Journal, Autumn

[67] Scandura T A, Williams E A, (2001), Research methodology in management: current practices trends and implications for future research, Academy of Management Journal, Vol. 43 No. 6, p1248

[68] Sentence A, Clarke J, (1997), The contribution of design to the UK economy, Centre for Economic Forecasting, London Business School

[69] Swann C, (2002), Action research and the practice of design, Design Issues, Vol. 18 No. 2

[70] Szakonyi, R. (1994a) Measuring R\&D effectiveness - I, Research Technology Management, 37(2):27-32

[71] Ulrich K T, Eppinger S D, (2000), Product design and development, McGraw-Hill, USA

[72] Urban G, Hauser J R, (1993), Design and marketing of new products: second edition, Prentice Hall, USA

[73] Utterback J, Allen T, Hollomon J, Sirbu M, (1976), The process of innovation in five industries in Europe and Japan, IEEE Transactions on Engineering Management, Vol. 23 No. 1, p3

[74] Walsh V, Roy R, Bruce M, Potter S, (1992), Winning by design: technology, product design and international competitiveness, Blackwell Business, Oxford

[75] Warmington A, (1980), Action research: its methods and its implications, Journal of Applied Systems Analysis, Vol. 7

[76] Wheelwright S. and Clark K. (1992), Creating Product Plans to Focus Product Development, Harvard Business Review March-April 1992. pp 70-82 


\section{[77] FIGURES \& TABLES}

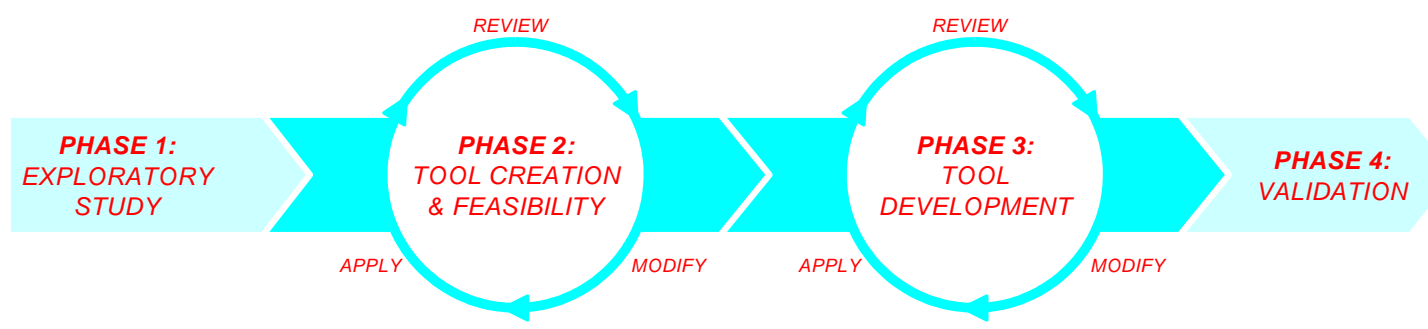
A: Optical medical products
E-J: Initial test cases
$\mathrm{K}$ : Consumer $\mathrm{Hi}-\mathrm{Fi}$
$\mathrm{N}$ : Medical lasers
Q-Y: Validation cases
$\mathrm{B}$ : Paper handling machinery
$\mathrm{L}$ : Building supplies
$\mathrm{D}$ : Industrial radios
M: Security Electronics
$\mathrm{O}$ : Specialist $\mathrm{Hi}-\mathrm{Fi}$
$\mathrm{P}$ : Agricultural machinery

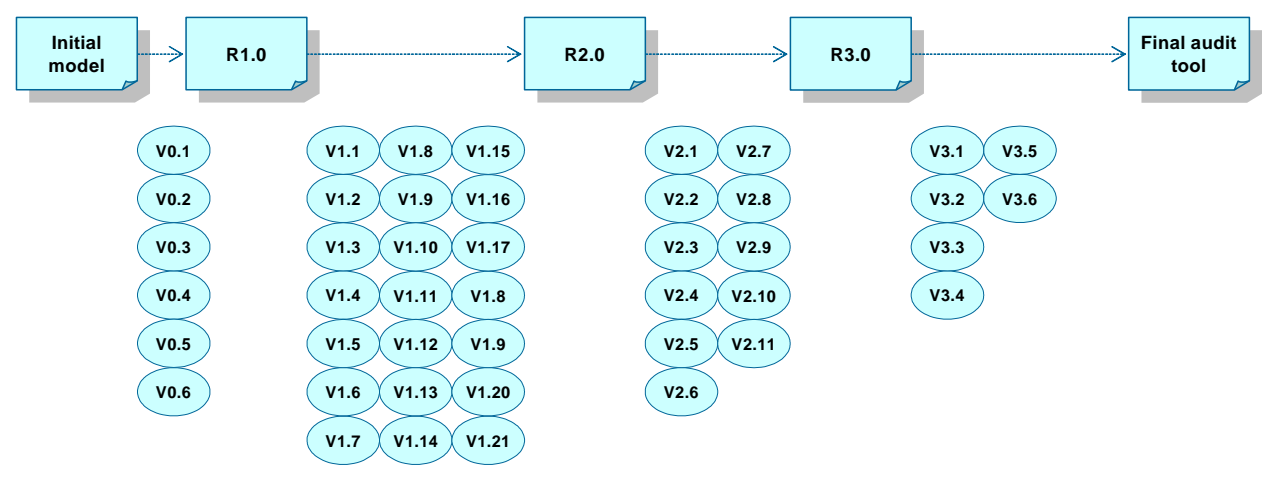

Figure 1: Research process and audit tool revisions

\begin{tabular}{|c|c|c|c|c|c|c|}
\hline \multicolumn{7}{|c|}{ Design execution: Requirements capture } \\
\hline Activity & $\begin{array}{l}\text { Level 1: } \\
\text { None / ad-hoc }\end{array}$ & $\begin{array}{l}\text { Level 2: } \\
\text { Partial }\end{array}$ & $\begin{array}{l}\text { Level 3: } \\
\text { Formal }\end{array}$ & $\begin{array}{l}\text { Level 4: } \\
\text { Culturally embedded }\end{array}$ & $\begin{array}{l}\text { Current } \\
\text { score } \\
(1-4)\end{array}$ & $\begin{array}{l}\text { Desired } \\
\text { score } \\
(1-4)\end{array}$ \\
\hline $\begin{array}{c}\text { Market } \\
\text { segmentation }\end{array}$ & $\begin{array}{l}\text { No obvious } \\
\text { segmentation }\end{array}$ & $\begin{array}{l}\text { Price based } \\
\text { segmentation }\end{array}$ & $\begin{array}{l}\text { Performance } \\
\text { based } \\
\text { segmentation }\end{array}$ & $\begin{array}{l}\text { Benefits based } \\
\text { segmentation }\end{array}$ & & \\
\hline $\begin{array}{l}\text { Competitive } \\
\text { analysis }\end{array}$ & $\begin{array}{l}\text { Little up to date } \\
\text { competitive } \\
\text { information }\end{array}$ & $\begin{array}{c}\text { Compare numbers } \\
\text { on brochures }\end{array}$ & $\begin{array}{c}\text { Good } \\
\text { understanding of } \\
\text { competitors }\end{array}$ & $\begin{array}{l}\text { Deep } \\
\text { understanding of } \\
\text { competitors }\end{array}$ & & \\
\hline $\begin{array}{l}\text { Investigating } \\
\text { user needs }\end{array}$ & $\begin{array}{l}\text { Rely on anecdote } \\
\text { and opinion }\end{array}$ & $\begin{array}{c}\text { Opinions } \\
\text { sometimes sought }\end{array}$ & $\begin{array}{c}\text { 'Voice of } \\
\text { Customer' a } \\
\text { standard process }\end{array}$ & $\begin{array}{l}\text { Range of methods } \\
\text { including empathic } \\
\text { research }\end{array}$ & & \\
\hline $\begin{array}{l}\text { Ongoing user } \\
\text { involvement }\end{array}$ & $\begin{array}{l}\text { Users rarely } \\
\text { involved }\end{array}$ & $\begin{array}{l}\text { Users sometimes } \\
\text { involved at start }\end{array}$ & $\begin{array}{l}\text { Users involved at } \\
\text { start and end }\end{array}$ & $\begin{array}{c}\text { Relevant } \\
\text { stakeholders } \\
\text { involved } \\
\text { throughout }\end{array}$ & & \\
\hline $\begin{array}{c}\text { Product } \\
\text { specification }\end{array}$ & $\begin{array}{l}\text { A poorly defined } \\
\text { wish list }\end{array}$ & $\begin{array}{l}\text { Different market } \\
\text { and technical } \\
\text { specs }\end{array}$ & $\begin{array}{l}\text { A single, testable } \\
\text { specification }\end{array}$ & $\begin{array}{l}\text { Unambiguous } \\
\text { USPs }\end{array}$ & & \\
\hline
\end{tabular}

Figure 2: Example summary grid of prcess audit for 'requirements capture' 


\section{Market segmentation}

"Market definition, segmentation and product positioning based on a clear understanding of customers and their needs"

\begin{tabular}{|c|c|c|c|c|c|}
\hline $\begin{array}{c}\text { Level 1: } \\
\text { No obvious } \\
\text { segmentation }\end{array}$ & $\begin{array}{c}\text { Level 2: } \\
\text { Price based } \\
\text { segmentation }\end{array}$ & $\begin{array}{c}\text { Level 3: } \\
\text { Performance based } \\
\text { segmentation }\end{array}$ & $\begin{array}{l}\text { Level 4: } \\
\text { Benefits based } \\
\text { segmentation }\end{array}$ & $\begin{array}{c}\text { Current } \\
\text { score } \\
(1-4)\end{array}$ & $\begin{array}{c}\text { Desired } \\
\text { score } \\
(1-4)\end{array}$ \\
\hline $\begin{array}{l}\text { - What is market } \\
\text { segmentation? } \\
\text { - No clearly defined } \\
\text { market segments } \\
\text { - Not sure who buys out } \\
\text { products or why }\end{array}$ & $\begin{array}{l}\text { - Segmentation based } \\
\text { on price - 'top end', } \\
\text { 'middle' and 'entry } \\
\text { level' } \\
\text { - Some overlap in } \\
\text { products } \\
\text { - No accurate data on } \\
\text { market size and share }\end{array}$ & $\begin{array}{l}\text { - Segmentation based } \\
\text { on product functionality } \\
\text { or performance } \\
\text { - Clear understanding of } \\
\text { the profiles of } \\
\text { customers in different } \\
\text { segments } \\
\text { - Understand the } \\
\text { competitors in each } \\
\text { segment }\end{array}$ & $\begin{array}{l}\text { - Segmentation based } \\
\text { on the benefits offered } \\
\text { to different types of } \\
\text { user } \\
\text { - Deep understanding of } \\
\text { the needs of users in } \\
\text { each segment } \\
\text { - Reliable data for each } \\
\text { segment }\end{array}$ & & \\
\hline
\end{tabular}

Figure 3: Example detailed grid of process audit for 'market segmentation'

Desirability ...

\begin{tabular}{|c|c|c|c|c|c|c|}
\hline Issue & Poor performance & \multicolumn{4}{|c|}{ Score (1-4) } & Great performance \\
\hline \multirow{4}{*}{ Aesthetics } & No visual novelty - it looks like all the rest & 1 & 2 & 3 & 4 & $\begin{array}{l}\text { Novel aesthetics give it a strong identity - visually } \\
\text { differentiated from competition }\end{array}$ \\
\hline & $\begin{array}{r}\text { No/too much 'contrast' between elements - tone, } \\
\text { shape, colour, line }\end{array}$ & 1 & 2 & 3 & 4 & $\begin{array}{l}\text { Just the right amount of 'contrast' between elements - } \\
\text { tone, shape, colour, line }\end{array}$ \\
\hline & $\begin{array}{r}\text { No sense of 'order' to the design - an incoherent and } \\
\text { inharmonious collection of elements }\end{array}$ & 1 & 2 & 3 & 4 & $\begin{array}{l}\text { A high sense of 'order' to the design - a pleasing } \\
\text { harmony of shapes, material, finish, colour and structure }\end{array}$ \\
\hline & $\begin{array}{l}\text { Its appearance is inappropriate and does not make } \\
\text { sense - it just looks wrong! }\end{array}$ & 1 & 2 & 3 & 4 & Its appearance makes complete sense - it just looks right! \\
\hline \multirow{3}{*}{$\begin{array}{l}\text { Symbolism } \\
\text { and status }\end{array}$} & $\begin{array}{r}\text { Ownership has no (or a detrimental) impact on 'status' } \\
\text { amongst the peer group of target market }\end{array}$ & 1 & 2 & 3 & 4 & $\begin{array}{l}\text { Ownership improves 'status' amongst the peer group of } \\
\text { target market }\end{array}$ \\
\hline & $\begin{array}{r}\text { It does not represent or express the tastes or values } \\
\text { of its target market }\end{array}$ & 1 & 2 & 3 & 4 & $\begin{array}{l}\text { It accurately symbolises or expresses the values, beliefs } \\
\text { and tastes of its target audience }\end{array}$ \\
\hline & $\begin{array}{r}\text { Appearance is inappropriate for the context or } \\
\text { environment of use }\end{array}$ & 1 & 2 & 3 & 4 & $\begin{array}{l}\text { Appearance is appropriate for the intended context or } \\
\text { environment of use }\end{array}$ \\
\hline \multirow{3}{*}{$\begin{array}{l}\text { Visual } \\
\text { clarity }\end{array}$} & $\begin{array}{r}\text { No clear brand identity or coherence across the full } \\
\text { product range }\end{array}$ & 1 & 2 & 3 & 4 & $\begin{array}{l}\text { Design reinforces and reflects the company's brand values } \\
\text { and identity }\end{array}$ \\
\hline & $\begin{array}{r}\text { Appearance is inconsistent with expected values - e.g. } \\
\text { tough, precious, fun etc }\end{array}$ & 1 & 2 & 3 & 4 & $\begin{array}{l}\text { Design expresses and reinforces specific qualities and } \\
\text { values - e.g. fast, accurate, tough etc. }\end{array}$ \\
\hline & $\begin{array}{l}\text { Confusing appearance which gives few clues to } \\
\text { describe the purpose and use of the product }\end{array}$ & 1 & 2 & 3 & 4 & $\begin{array}{l}\text { Appearance helps to clearly describe the product } \\
\text { purpose, function and operation }\end{array}$ \\
\hline All senses & $\begin{array}{r}\text { Feels, smells or sounds horrible - little sensory } \\
\text { pleasure (touch, feel etc) }\end{array}$ & 1 & 2 & 3 & 4 & $\begin{array}{l}\text { Feels as good as it looks: Sensual pleasure through } \\
\text { comfort, material or texture }\end{array}$ \\
\hline Pride & $\begin{array}{r}\text { Little pride of ownership, design is utilitarian and } \\
\text { functional - it gets hidden away }\end{array}$ & 1 & 2 & 3 & 4 & $\begin{array}{l}\text { Design inspires a sense of pride in buying and owning - it } \\
\text { may even go on display }\end{array}$ \\
\hline \multirow[t]{2}{*}{$\begin{array}{l}\text { Emotional } \\
\text { response }\end{array}$} & $\begin{array}{l}\text { Product produces a negative emotional response - it } \\
\text { makes me feel cross, frustrated, angry, upset etc. }\end{array}$ & 1 & 2 & 3 & 4 & $\begin{array}{l}\text { Product produces a positive emotional response - it } \\
\text { makes me feel happy, satisfied, reassured etc. }\end{array}$ \\
\hline & Overall low desirability & 1 & 2 & 3 & 4 & Overall high desirability \\
\hline
\end{tabular}

Figure 4: example product audit worksheet - product desirability 


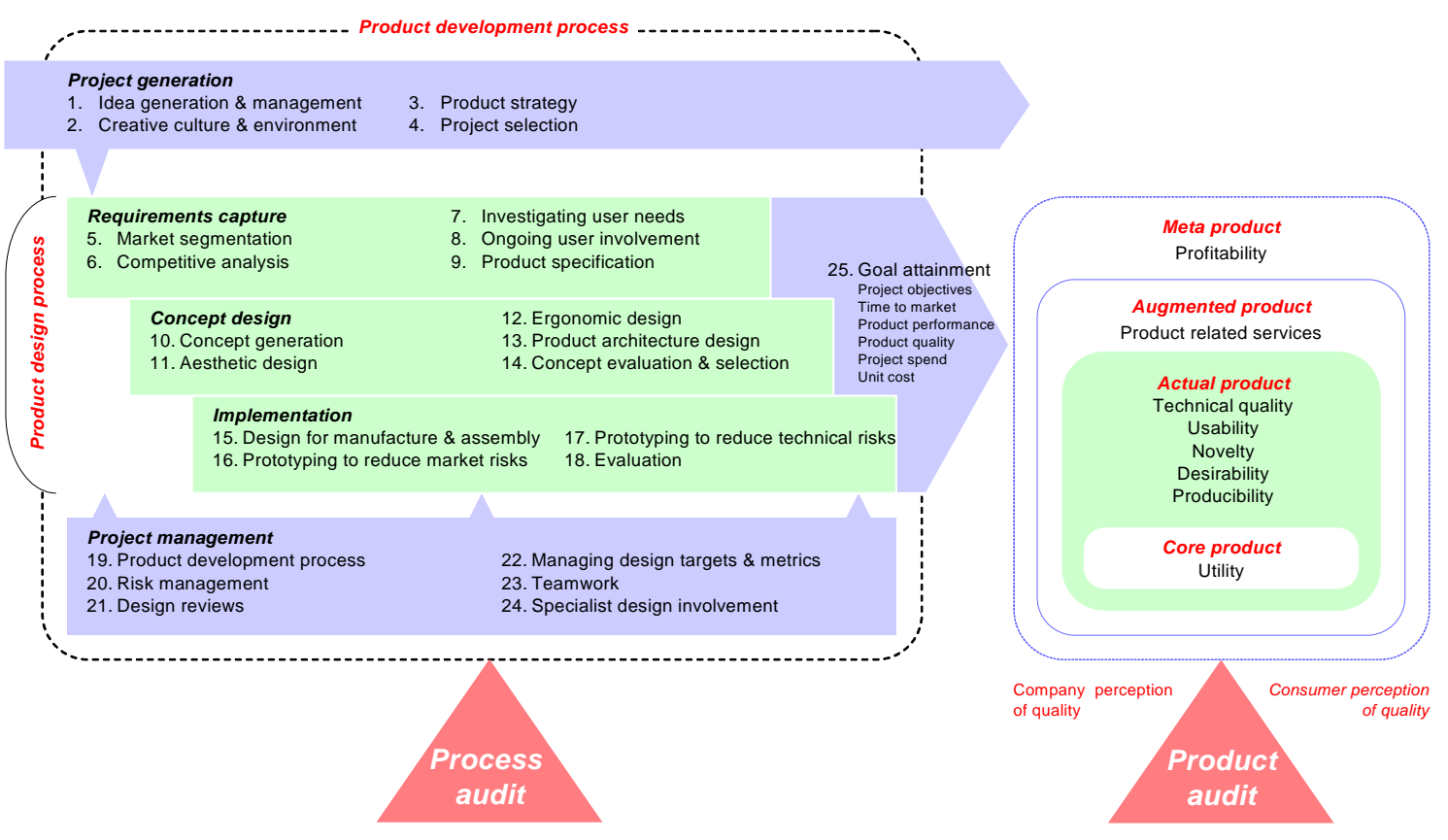

Figure 5: Structure of the design audit - product and process

\begin{tabular}{|c|c|c|c|c|}
\hline & Case company & Sector / Products & $\mathrm{T} / \mathrm{O} \mathrm{Em}$ & Staff \\
\hline \multirow{4}{*}{ 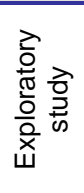 } & A & Optical medical products & $£ 12.0 \mathrm{~m}$ & 133 \\
\hline & $B$ & Paper handling and collation & $£ 4.0 \mathrm{~m}$ & 80 \\
\hline & C & Medical emergency products & $£ 5.5 \mathrm{~m}$ & 100 \\
\hline & $\mathrm{D}$ & Industrial radios & NA & NA \\
\hline \multirow{9}{*}{ 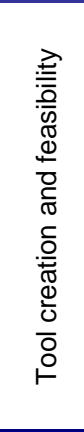 } & $E$ & Scientific instruments & $£ 1.2 \mathrm{~m}$ & 25 \\
\hline & $\mathrm{F}$ & Industrial ink-jet printing & $£ 150 \mathrm{~m}$ & 1500 \\
\hline & $\mathrm{G}$ & Software & $£ 3.0 \mathrm{~m}$ & 45 \\
\hline & $\mathrm{H}$ & Design consultancy & $£ 1.0 \mathrm{~m}$ & 12 \\
\hline & I & Food machinery & $£ 20.0 \mathrm{~m}$ & 200 \\
\hline & $\mathrm{J}$ & Consumer tools & NA & NA \\
\hline & $\mathrm{K}$ & Consumer $\mathrm{Hi}-\mathrm{Fi}$ & $£ 10.0 \mathrm{~m}$ & 110 \\
\hline & $\mathrm{L}$ & Building supplies & $£ 15.0 \mathrm{~m}$ & 250 \\
\hline & M & Security electronics & $£ 3.0 \mathrm{M}$ & 50 \\
\hline \multirow{3}{*}{ 잉 } & $\mathrm{N}$ & Medical lasers & $£ 6.0 \mathrm{~m}$ & 70 \\
\hline & $\mathrm{O}$ & Specialist Hi-Fi & $£ 3.5 \mathrm{~m}$ & 30 \\
\hline & $\mathrm{P}$ & Agricultural machinery & $£ 9.0 \mathrm{~m}$ & 130 \\
\hline \multirow{10}{*}{ 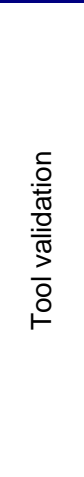 } & Q & Instrumentation: Spectrometers & $£ 10 \mathrm{~m}$ & 75 \\
\hline & $\mathrm{R}$ & Instrumentation: Sensors & $£ 540 \mathrm{~m}$ (Group) & 660 (Group) \\
\hline & $\mathrm{S}$ & Instrumentation: Scientific equipment & $£ 6 \mathrm{~m}$ & 100 \\
\hline & $\mathrm{T}$ & Instrumentation: Hygrometers & $£ 5 \mathrm{~m}$ & 60 \\
\hline & $\mathrm{U}$ & Instrumentation: Sensing \& control & Group £23bn & Group 15,000 \\
\hline & $\mathrm{V}$ & Consumer electronics: Audio & $£ 3.5 \mathrm{~m}$ & 30 \\
\hline & W & Consumer goods: White goods & $>£ 20 \mathrm{~m}$ & $>200$ \\
\hline & $x$ & Industrial goods: Building supplies & $£ 15 m$ & 275 \\
\hline & Y & Consumer electronics: Audio & $£ 4 \mathrm{~m}$ & 45 \\
\hline & Z & Design consultancy & $£ 0.75 \mathrm{~m}$ & 12 \\
\hline
\end{tabular}

Table 1: Summary of cases 


\section{APPENDIX 1: PROCESS AUDIT SUMMARY GRIDS}

\begin{tabular}{|c|c|c|c|c|c|c|}
\hline Activity & $\begin{array}{c}\text { Level 1: } \\
\text { None / ad-hoc }\end{array}$ & $\begin{array}{l}\text { Level 2: } \\
\text { Partial }\end{array}$ & $\begin{array}{l}\text { Level 3: } \\
\text { Formal }\end{array}$ & $\begin{array}{c}\text { Level 4: } \\
\text { Culturally embedded }\end{array}$ & $\begin{array}{l}\text { Current } \\
\text { score } \\
(1-4)\end{array}$ & $\begin{array}{c}\text { Desired } \\
\text { score } \\
(1-4)\end{array}$ \\
\hline $\begin{array}{c}\text { Market } \\
\text { segmentation }\end{array}$ & $\begin{array}{l}\text { No obvious } \\
\text { segmentation }\end{array}$ & $\begin{array}{l}\text { Price based } \\
\text { segmentation }\end{array}$ & $\begin{array}{l}\text { Performance } \\
\text { based } \\
\text { segmentation }\end{array}$ & $\begin{array}{l}\text { Benefits based } \\
\text { segmentation }\end{array}$ & & \\
\hline $\begin{array}{l}\text { Competitive } \\
\text { analysis }\end{array}$ & $\begin{array}{l}\text { Little up to date } \\
\text { competitive } \\
\text { information }\end{array}$ & $\begin{array}{l}\text { Compare numbers } \\
\text { on brochures }\end{array}$ & $\begin{array}{c}\text { Good } \\
\text { understanding of } \\
\text { competitors }\end{array}$ & $\begin{array}{l}\text { Deep } \\
\text { understanding of } \\
\text { competitors }\end{array}$ & & \\
\hline $\begin{array}{l}\text { Investigating } \\
\text { user needs }\end{array}$ & $\begin{array}{l}\text { Rely on anecdote } \\
\text { and opinion }\end{array}$ & $\begin{array}{c}\text { Opinions } \\
\text { sometimes sought }\end{array}$ & $\begin{array}{c}\text { 'Voice of } \\
\text { Customer' a } \\
\text { standard process }\end{array}$ & $\begin{array}{l}\text { Range of methods } \\
\text { including empathic } \\
\text { research }\end{array}$ & & \\
\hline $\begin{array}{l}\text { Ongoing user } \\
\text { involvement }\end{array}$ & $\begin{array}{l}\text { Users rarely } \\
\text { involved }\end{array}$ & $\begin{array}{l}\text { Users sometimes } \\
\text { involved at start }\end{array}$ & $\begin{array}{l}\text { Users involved at } \\
\text { start and end }\end{array}$ & $\begin{array}{l}\text { Relevant } \\
\text { stakeholders } \\
\text { involved } \\
\text { throughout }\end{array}$ & & \\
\hline $\begin{array}{c}\text { Product } \\
\text { specification }\end{array}$ & $\begin{array}{l}\text { A poorly defined } \\
\text { wish list }\end{array}$ & $\begin{array}{l}\text { Different market } \\
\text { and technical } \\
\text { specs }\end{array}$ & $\begin{array}{l}\text { A single, testable } \\
\text { specification }\end{array}$ & $\begin{array}{c}\text { Unambiguous } \\
\text { USPs }\end{array}$ & & \\
\hline
\end{tabular}

Design execution: Concept design

\begin{tabular}{|c|c|c|c|c|c|c|}
\hline Activity & $\begin{array}{c}\text { Level 1: } \\
\text { None / ad-hoc }\end{array}$ & $\begin{array}{l}\text { Level 2: } \\
\text { Partial }\end{array}$ & $\begin{array}{l}\text { Level 3: } \\
\text { Formal }\end{array}$ & $\begin{array}{l}\text { Level 4: } \\
\text { Culturally embedded }\end{array}$ & $\begin{array}{l}\text { Current } \\
\text { score } \\
(1-4)\end{array}$ & $\begin{array}{l}\text { Desired } \\
\text { score } \\
(1-4)\end{array}$ \\
\hline $\begin{array}{c}\text { Concept } \\
\text { generation }\end{array}$ & $\begin{array}{l}\text { Go with the first } \\
\text { idea }\end{array}$ & $\begin{array}{c}\text { Engineering led } \\
\text { concept generation }\end{array}$ & $\begin{array}{l}\text { X-functional } \\
\text { involvement }\end{array}$ & $\begin{array}{l}\text { Radical ideas } \\
\text { encouraged }\end{array}$ & & \\
\hline $\begin{array}{c}\text { Aesthetic } \\
\text { design }\end{array}$ & $\begin{array}{l}\text { Looks don't matter, } \\
\text { performance does }\end{array}$ & $\begin{array}{c}\text { Technology } \\
\text { sometimes 'styled' }\end{array}$ & $\begin{array}{l}\text { Aesthetics critical } \\
\text { for differentiation }\end{array}$ & $\begin{array}{l}\text { Design leaders in } \\
\text { our industry }\end{array}$ & & \\
\hline $\begin{array}{c}\text { Ergonomic } \\
\text { design }\end{array}$ & $\begin{array}{l}\text { Little consideration } \\
\text { of usability }\end{array}$ & $\begin{array}{l}\text { Engineers design } \\
\text { user interface }\end{array}$ & $\begin{array}{l}\text { Early specialist } \\
\text { involvement }\end{array}$ & $\begin{array}{c}\text { Total 'user } \\
\text { experience' design }\end{array}$ & & \\
\hline $\begin{array}{c}\text { Product } \\
\text { architecture } \\
\text { design }\end{array}$ & $\begin{array}{l}\text { Configuration } \\
\text { evolves ad-hoc }\end{array}$ & $\begin{array}{c}\text { Intuitively consider } \\
\text { modularity }\end{array}$ & $\begin{array}{c}\text { Formal } \\
\text { architecture } \\
\text { planning }\end{array}$ & $\begin{array}{l}\text { Platform based } \\
\text { product strategy }\end{array}$ & & \\
\hline $\begin{array}{c}\text { Concept } \\
\text { evaluation \& } \\
\text { selection }\end{array}$ & $\begin{array}{l}\text { There is only one } \\
\text { concept }\end{array}$ & $\begin{array}{l}\text { "Chosen by the } \\
\text { Chairman's wife" }\end{array}$ & $\begin{array}{l}\text { Internal } \\
\text { stakeholders } \\
\text { involved }\end{array}$ & $\begin{array}{l}\text { Internal and } \\
\text { external } \\
\text { stakeholders } \\
\text { involved }\end{array}$ & & \\
\hline
\end{tabular}


Design execution: Implementation

\begin{tabular}{|c|c|c|c|c|c|c|}
\hline Activity & $\begin{array}{c}\text { Level 1: } \\
\text { None / ad-hoc }\end{array}$ & $\begin{array}{l}\text { Level 2: } \\
\text { Partial }\end{array}$ & $\begin{array}{l}\text { Level 3: } \\
\text { Formal }\end{array}$ & $\begin{array}{c}\text { Level 4: } \\
\text { Culturally embedded }\end{array}$ & $\begin{array}{l}\text { Current } \\
\text { score } \\
(1-4)\end{array}$ & $\begin{array}{l}\text { Desired } \\
\text { score } \\
(1-4)\end{array}$ \\
\hline $\begin{array}{c}\text { Design for } \\
\text { manufacture \& } \\
\text { assembly }\end{array}$ & Over the wall & $\begin{array}{c}\text { Ad-hoc } \\
\text { manufacturing } \\
\text { involvement }\end{array}$ & $\begin{array}{l}\text { Regular design } \\
\text { reviews with } \\
\text { manufacturing }\end{array}$ & $\begin{array}{c}\text { Formal use of DfM } \\
\text { and DfA } \\
\text { techniques }\end{array}$ & & \\
\hline $\begin{array}{l}\text { Prototyping to } \\
\text { reduce market } \\
\text { risks }\end{array}$ & Trust me it'll sell & $\begin{array}{l}\text { Occasional user } \\
\text { testing }\end{array}$ & $\begin{array}{c}\text { Always test with } \\
\text { users }\end{array}$ & $\begin{array}{l}\text { Hi-Fi \& Lo-Fi } \\
\text { modelling a way of } \\
\text { life }\end{array}$ & & \\
\hline $\begin{array}{l}\text { Prototyping to } \\
\text { reduce } \\
\text { technical risks }\end{array}$ & Trust me it'll work & $\begin{array}{l}\text { Pre-production } \\
\text { prototypes }\end{array}$ & $\begin{array}{l}\text { Prototype all risky } \\
\text { elements }\end{array}$ & $\begin{array}{l}\text { Hi-Fi \& Lo-Fi } \\
\text { modelling a way of } \\
\text { life }\end{array}$ & & \\
\hline Evaluation & $\begin{array}{c}\text { Customers do the } \\
\text { QA }\end{array}$ & $\begin{array}{l}\text { Minimal evaluation } \\
\text { - no time or plan }\end{array}$ & $\begin{array}{c}\text { Engineering } \\
\text { evaluation - to a } \\
\text { plan }\end{array}$ & $\begin{array}{c}\text { Independent pre \& } \\
\text { post launch } \\
\text { evaluation }\end{array}$ & & \\
\hline
\end{tabular}

Design management: project generation

\begin{tabular}{|c|c|c|c|c|c|c|}
\hline Activity & $\begin{array}{c}\text { Level 1: } \\
\text { None / ad-hoc }\end{array}$ & $\begin{array}{l}\text { Level 2: } \\
\text { Partial }\end{array}$ & $\begin{array}{l}\text { Level 3: } \\
\text { Formal }\end{array}$ & $\begin{array}{l}\text { Level 4: } \\
\text { Culturally embedded }\end{array}$ & $\begin{array}{l}\text { Current } \\
\text { score } \\
(1-4)\end{array}$ & $\begin{array}{l}\text { Desired } \\
\text { score } \\
(1-4)\end{array}$ \\
\hline $\begin{array}{l}\text { Idea generation } \\
\text { \& management }\end{array}$ & $\begin{array}{c}\text { No idea } \\
\text { management - } \\
\text { flavour of the } \\
\text { month }\end{array}$ & $\begin{array}{l}\text { Ideas generated \& } \\
\text { then forgotten }\end{array}$ & $\begin{array}{l}\text { Formal idea } \\
\text { management }\end{array}$ & $\begin{array}{l}\text { IT tools used to } \\
\text { manage and } \\
\text { encourage ideas }\end{array}$ & & \\
\hline $\begin{array}{c}\text { Creative } \\
\text { culture \& } \\
\text { environment }\end{array}$ & No playing at all & $\begin{array}{l}\text { Creativity kept } \\
\text { 'under the desk' }\end{array}$ & $\begin{array}{l}\text { Some managed } \\
\text { 'play time' }\end{array}$ & $\begin{array}{c}\text { Creativity expected } \\
\& \text { rewarded }\end{array}$ & & \\
\hline $\begin{array}{l}\text { Product } \\
\text { strategy }\end{array}$ & $\begin{array}{l}\text { One project at a } \\
\text { time }\end{array}$ & $\begin{array}{c}\text { A strategy exists - } \\
\text { but ... }\end{array}$ & Medium term view & $\begin{array}{l}\text { Shared long term } \\
\text { vision }\end{array}$ & & \\
\hline $\begin{array}{l}\text { Project } \\
\text { selection }\end{array}$ & $\begin{array}{l}\text { Next project } \\
\text { chooses itself }\end{array}$ & $\begin{array}{c}\text { Whoever shouts } \\
\text { the loudest }\end{array}$ & $\begin{array}{c}\text { Thorough business } \\
\text { case }\end{array}$ & $\begin{array}{l}\text { Balanced project } \\
\text { portfolio }\end{array}$ & & \\
\hline
\end{tabular}


Design management: project management

\begin{tabular}{|c|c|c|c|c|c|c|}
\hline Activity & $\begin{array}{c}\text { Level 1: } \\
\text { None / ad-hoc }\end{array}$ & $\begin{array}{l}\text { Level 2: } \\
\text { Partial }\end{array}$ & $\begin{array}{l}\text { Level 3: } \\
\text { Formal }\end{array}$ & $\begin{array}{l}\text { Level 4: } \\
\text { Culturally embedded }\end{array}$ & $\begin{array}{l}\text { Current } \\
\text { score } \\
(1-4)\end{array}$ & $\begin{array}{l}\text { Desired } \\
\text { score } \\
(1-4)\end{array}$ \\
\hline $\begin{array}{l}\text { Product } \\
\text { development } \\
\text { process }\end{array}$ & No process & $\begin{array}{c}\text { A process exists - } \\
\text { but } \ldots\end{array}$ & $\begin{array}{l}\text { Process used and } \\
\text { understood }\end{array}$ & $\begin{array}{l}\text { Continuous } \\
\text { process } \\
\text { improvement }\end{array}$ & & \\
\hline $\begin{array}{c}\text { Risk } \\
\text { management }\end{array}$ & $\begin{array}{l}\text { Press on } \\
\text { regardless }\end{array}$ & $\begin{array}{l}\text { Aware of most } \\
\text { technical risks }\end{array}$ & $\begin{array}{l}\text { Formal } \\
\text { management of } \\
\text { risks }\end{array}$ & $\begin{array}{c}\text { Proactively } \\
\text { manage risks }\end{array}$ & & \\
\hline Design reviews & No design reviews & $\begin{array}{c}\text { Design reviews at } \\
\text { crisis }\end{array}$ & $\begin{array}{l}\text { Periodic formal } \\
\text { reviews }\end{array}$ & $\begin{array}{l}\text { Regular formal and } \\
\text { informal reviews }\end{array}$ & & \\
\hline $\begin{array}{l}\text { Management of } \\
\text { design targets } \\
\text { \& metrics }\end{array}$ & $\begin{array}{c}\text { No targets - point } \\
\& \text { shoot }\end{array}$ & $\begin{array}{l}\text { Targets - but } \\
\text { goalposts keep } \\
\text { moving }\end{array}$ & $\begin{array}{l}\text { Targets set and } \\
\text { partially managed }\end{array}$ & $\begin{array}{c}\text { Balanced } \\
\text { scorecard of } \\
\text { project measures }\end{array}$ & & \\
\hline Teamwork & Functional rivalry & $\begin{array}{l}\text { Lightweight project } \\
\text { management }\end{array}$ & $\begin{array}{l}\text { Heavyweight } \\
\text { project } \\
\text { management }\end{array}$ & $\begin{array}{l}\text { Autonomous } \\
\text { project teams }\end{array}$ & & \\
\hline $\begin{array}{l}\text { Specialist } \\
\text { design } \\
\text { involvement }\end{array}$ & $\begin{array}{l}\text { Not used - } \\
\text { 'silent design' }\end{array}$ & $\begin{array}{l}\text { Specialists come } \\
\text { in late to 'tart up' } \\
\text { the product }\end{array}$ & $\begin{array}{c}\text { Early specialist } \\
\text { input }\end{array}$ & $\begin{array}{c}\text { Strategic specialist } \\
\text { input }\end{array}$ & & \\
\hline
\end{tabular}




\section{APPENDIX 2: PRODUCT AUDIT}

\section{Core benefits ...}

\begin{tabular}{|c|c|c|c|c|c|c|}
\hline \multirow{2}{*}{$\begin{array}{l}\text { Issue } \\
\text { Need }\end{array}$} & \multirow{2}{*}{$\begin{array}{r}\text { Poor performance } \\
\begin{array}{r}\text { Why would I need it? - Not obvious what benefits the } \\
\text { target audience would gain from using it }\end{array}\end{array}$} & \multicolumn{4}{|c|}{ Score (1-4) } & \multirow{2}{*}{$\begin{array}{l}\text { Great performance } \\
\text { Will save its target market time, money or effort } \& \text { is } \\
\text { absolutely essential - benefits are obvious }\end{array}$} \\
\hline & & 1 & 2 & 3 & 4 & \\
\hline Functionality & Too much or too little functionality to be really useful & 1 & 2 & 3 & 4 & Appropriate level of functionality - and no more \\
\hline Alternatives & $\begin{array}{r}\text { Lots of alternatives out there perform the same function } \\
- \text { often better }\end{array}$ & 1 & 2 & 3 & 4 & $\begin{array}{l}\text { There are no viable alternatives to this product - which } \\
\text { have the same capabilities }\end{array}$ \\
\hline \multirow[t]{2}{*}{ Value } & $\begin{array}{r}\text { Would buy if it was really needed - but would pay the } \\
\text { absolute minimum }\end{array}$ & 1 & 2 & 3 & 4 & Would pay a premium - even if it wasn't really needed \\
\hline & Overall few real benefits & 1 & 2 & 3 & 4 & Overall significant benefits \\
\hline
\end{tabular}

Engineering quality ...

\begin{tabular}{|rr|r|r|r|r|r}
\multicolumn{1}{c|}{ Issue } & Poor performance & \multicolumn{3}{|c|}{ Score (1-4) } & Great performance \\
\hline Performance & Over promises and under performs & 1 & 2 & 3 & 4 & Performance exceeds expectations \\
\hline Reliability & Unreliable - regularly fails to work correctly & 1 & 2 & 3 & 4 & A work horse $-100 \%$ reliability \\
\hline Build quality & Poor build quality - looks and feels cheap & 1 & 2 & 3 & 4 & Solidly built and well engineered \\
\hline Durability & Poor durability - likely to break or stop working & 1 & 2 & 3 & 4 & $110 \%$ durability - will outlast the competition \\
\hline Overall poor engineering quality & 1 & 2 & 3 & 4 & Overall great engineering quality
\end{tabular}

\section{Profitability ...}

\begin{tabular}{|c|c|c|c|c|c|c|}
\hline \multirow{2}{*}{$\begin{array}{l}\text { Issue } \\
\text { Income }\end{array}$} & \multirow{2}{*}{$\begin{array}{l}\text { Poor performance } \\
\text { Lower income than planned }\end{array}$} & \multicolumn{4}{|c|}{ Score (1-4) } & \multirow{2}{*}{$\begin{array}{l}\text { Great performance } \\
\text { Income exceeds expectations }\end{array}$} \\
\hline & & 1 & 2 & 3 & 4 & \\
\hline $\begin{array}{l}\text { Production } \\
\text { costs }\end{array}$ & Unit cost too high & 1 & 2 & 3 & 4 & Unit cost lower than expected \\
\hline $\begin{array}{c}\text { Selling \& } \\
\text { support costs }\end{array}$ & Costs too much to sell and support & 1 & 2 & 3 & 4 & Selling and support costs lower than expected \\
\hline $\begin{array}{l}\text { Profit (per } \\
\text { unit) }\end{array}$ & Margins are too low & 1 & 2 & 3 & 4 & Margins exceed expectations \\
\hline \multirow[t]{2}{*}{ Market share } & Small share of a shrinking market & 1 & 2 & 3 & 4 & Good share of a growing market \\
\hline & Overall poor profitability & 1 & 2 & 3 & 4 & Overall good profitability \\
\hline
\end{tabular}




\begin{tabular}{|c|c|c|c|c|c|c|}
\hline \multirow[t]{2}{*}{ Issue } & \multirow{2}{*}{$\begin{array}{r}\text { Poor performance } \\
\begin{array}{r}\text { Poor packaging - difficult to get into, waste of materials, } \\
\text { and unclear instructions / graphics }\end{array}\end{array}$} & \multicolumn{4}{|c|}{ Score (1-4) } & \multirow{2}{*}{$\begin{array}{l}\text { Great performance } \\
\begin{array}{l}\text { Great packaging - easy to access, beautifully designed, } \\
\text { unambiguous and obvious how to access }\end{array} \\
\end{array}$} \\
\hline & & 1 & 2 & 3 & 4 & \\
\hline \multirow[t]{5}{*}{$\begin{array}{l}\text { Getting } \\
\text { started }\end{array}$} & Needs several weeks of training just to get started & 1 & 2 & 3 & 4 & Training either not needed or well provided \\
\hline & Handbook, manual or documentation next to useless & 1 & 2 & 3 & 4 & Supporting documentation is clear, concise and useful \\
\hline & User interface ignores accepted rules and conventions & 1 & 2 & 3 & 4 & $\begin{array}{l}\text { Interface follows (or improves) accepted rules \& } \\
\text { conventions - it is compatible with similar devices }\end{array}$ \\
\hline & Little layering of information or prioritisation of functions & 1 & 2 & 3 & 4 & $\begin{array}{l}\text { The most important information/functions are the most } \\
\text { accessible and are clearly prioritised }\end{array}$ \\
\hline & Frequent \& unrecoverable errors & 1 & 2 & 3 & 4 & $\begin{array}{l}\text { Little likelihood of errors - but when they happen, recovery } \\
\text { is simple }\end{array}$ \\
\hline \multirow[t]{4}{*}{$\begin{array}{l}\text { Interface } \\
\text { clarity }\end{array}$} & Little or no feedback between action and effect & 1 & 2 & 3 & 4 & $\begin{array}{l}\text { Clear \& obvious feedback lets you know when actions are } \\
\text { performed }\end{array}$ \\
\hline & $\begin{array}{r}\text { Little or no natural mapping between controls and } \\
\text { resulting actions }\end{array}$ & 1 & 2 & 3 & 4 & $\begin{array}{l}\text { Clear \& obvious natural mapping between controls \& } \\
\text { resulting actions }\end{array}$ \\
\hline & $\begin{array}{r}\text { Few designed in-constraints to prevent errors or guide } \\
\text { actions }\end{array}$ & 1 & 2 & 3 & 4 & $\begin{array}{l}\text { Appropriate constraints designed in to prevent errors and } \\
\text { guide actions }\end{array}$ \\
\hline & $\begin{array}{r}\text { Interface is unlikely to be understood by much of the } \\
\text { target population }\end{array}$ & 1 & 2 & 3 & 4 & $\begin{array}{l}\text { Interface will be understood by both the target and the } \\
\text { wider population }\end{array}$ \\
\hline \multirow{2}{*}{$\begin{array}{l}\text { Physical } \\
\text { usability }\end{array}$} & $\begin{array}{r}\text { Physical elements have the wrong size, shape and } \\
\text { arrangement to be used comfortably }\end{array}$ & 1 & 2 & 3 & 4 & $\begin{array}{l}\text { All elements have the right size, shape and arrangement } \\
\text { for users in the target population }\end{array}$ \\
\hline & $\begin{array}{r}\text { Size, shape or position of elements cannot be adjusted } \\
\text { to suit the needs of different users }\end{array}$ & 1 & 2 & 3 & 4 & All necessary adjustments well catered for \\
\hline \multirow{2}{*}{$\begin{array}{l}\text { Maintenance } \\
\& \text { Cleaning }\end{array}$} & $\begin{array}{r}\text { Difficult to service, maintain \& repair - specialist input is } \\
\text { expensive / unavailable }\end{array}$ & 1 & 2 & 3 & 4 & $\begin{array}{l}\text { Service, maintenance \& repair either simple or not needed } \\
\text { - specialist input is readily available }\end{array}$ \\
\hline & $\begin{array}{r}\text { Difficult-to clean - nooks, crannies and hard-to-access } \\
\text { areas or easily damaged materials }\end{array}$ & 1 & 2 & 3 & 4 & $\begin{array}{l}\text { Easy to clean - appropriate materials, easy access, smooth } \\
\text { surfaces, clear visibility }\end{array}$ \\
\hline
\end{tabular}

\section{Desirability ...}

\begin{tabular}{|c|c|c|c|c|c|c|}
\hline Issue & Poor performance & \multicolumn{4}{|c|}{ Score (1-4) } & Great performance \\
\hline \multirow{4}{*}{ Aesthetics } & No visual novelty - it looks like all the rest & 1 & 2 & 3 & 4 & $\begin{array}{l}\text { Novel aesthetics give it a strong identity - visually } \\
\text { differentiated from competition }\end{array}$ \\
\hline & $\begin{array}{r}\text { No/too much 'contrast' between elements - tone, } \\
\text { shape, colour, line }\end{array}$ & 1 & 2 & 3 & 4 & $\begin{array}{l}\text { Just the right amount of 'contrast' between elements - } \\
\text { tone, shape, colour, line }\end{array}$ \\
\hline & $\begin{array}{r}\text { No sense of 'order' to the design - an incoherent and } \\
\text { inharmonious collection of elements }\end{array}$ & 1 & 2 & 3 & 4 & $\begin{array}{l}\text { A high sense of 'order' to the design - a pleasing harmony } \\
\text { of shapes, material, finish, colour and structure }\end{array}$ \\
\hline & $\begin{array}{r}\text { Its appearance is inappropriate and does not make } \\
\text { sense - it just looks wrong! }\end{array}$ & 1 & 2 & 3 & 4 & Its appearance makes complete sense - it just looks right! \\
\hline \multirow{3}{*}{$\begin{array}{l}\text { Symbolism } \\
\text { and status }\end{array}$} & $\begin{array}{r}\text { Ownership has no (or a detrimental) impact on 'status' } \\
\text { amongst the peer group of target market }\end{array}$ & 1 & 2 & 3 & 4 & $\begin{array}{l}\text { Ownership improves 'status' amongst the peer group of } \\
\text { target market }\end{array}$ \\
\hline & $\begin{array}{r}\text { It does not represent or express the tastes or values of } \\
\text { its target market }\end{array}$ & 1 & 2 & 3 & 4 & $\begin{array}{l}\text { It accurately symbolises or expresses the values, beliefs } \\
\text { and tastes of its target audience }\end{array}$ \\
\hline & $\begin{array}{r}\text { Appearance is inappropriate for the context or } \\
\text { environment of use }\end{array}$ & 1 & 2 & 3 & 4 & $\begin{array}{l}\text { Appearance is appropriate for the intended context or } \\
\text { environment of use }\end{array}$ \\
\hline \multirow{3}{*}{ Visual clarity } & $\begin{array}{r}\text { No clear brand identity or coherence across the full } \\
\text { product range }\end{array}$ & 1 & 2 & 3 & 4 & $\begin{array}{l}\text { Design reinforces and reflects the company's brand values } \\
\text { and identity }\end{array}$ \\
\hline & $\begin{array}{r}\text { Appearance is inconsistent with expected values - e.g. } \\
\text { tough, precious, fun etc }\end{array}$ & 1 & 2 & 3 & 4 & $\begin{array}{l}\text { Design expresses and reinforces specific qualities and } \\
\text { values - e.g. fast, accurate, tough etc. }\end{array}$ \\
\hline & $\begin{array}{l}\text { Confusing appearance which gives few clues to } \\
\text { describe the purpose and use of the product }\end{array}$ & 1 & 2 & 3 & 4 & $\begin{array}{l}\text { Appearance helps to clearly describe the product purpose, } \\
\text { function and operation }\end{array}$ \\
\hline All senses & $\begin{array}{r}\text { Feels, smells or sounds horrible - little sensory } \\
\text { pleasure (touch, feel etc) }\end{array}$ & 1 & 2 & 3 & 4 & $\begin{array}{l}\text { Feels as good as it looks: Sensual pleasure through } \\
\text { comfort, material or texture }\end{array}$ \\
\hline Pride & $\begin{array}{r}\text { Little pride of ownership, design is utilitarian and } \\
\text { functional - it gets hidden away }\end{array}$ & 1 & 2 & 3 & 4 & $\begin{array}{l}\text { Design inspires a sense of pride in buying and owning - it } \\
\text { may even go on display }\end{array}$ \\
\hline \multirow[t]{2}{*}{$\begin{array}{l}\text { Emotional } \\
\text { response }\end{array}$} & $\begin{array}{l}\text { Product produces a negative emotional response - it } \\
\text { makes me feel cross, frustrated, angry, upset etc. }\end{array}$ & 1 & 2 & 3 & 4 & $\begin{array}{l}\text { Product produces a positive emotional response - it makes } \\
\text { me feel happy, satisfied, reassured etc. }\end{array}$ \\
\hline & Overall low desirability & 1 & 2 & 3 & 4 & Overall high desirability \\
\hline
\end{tabular}




\section{Producibility ...}

\begin{tabular}{|c|c|c|c|c|c|c|}
\hline Issue & Poor performance & \multicolumn{4}{|c|}{ Score (1-4) } & Great performance \\
\hline \multirow{3}{*}{$\begin{array}{l}\text { Component } \\
\text { manufacture }\end{array}$} & Too many parts - over engineered & 1 & 2 & 3 & 4 & $\begin{array}{l}\text { Optimum (minimum) number of parts - each 'explains' its } \\
\text { reason for being there }\end{array}$ \\
\hline & $\begin{array}{l}\text { Several 'critical' components which are difficult to } \\
\text { produce - lots of scrap and rework }\end{array}$ & 1 & 2 & 3 & 4 & $\begin{array}{l}\text { No 'critical' components and hence little scrap or rework - } \\
\text { all components simple to produce }\end{array}$ \\
\hline & $\begin{array}{r}\text { New components added without considering reusing } \\
\text { existing ones }\end{array}$ & 1 & 2 & 3 & 4 & $\begin{array}{l}\text { No new components added without first considering } \\
\text { reusing existing ones }\end{array}$ \\
\hline \multirow{8}{*}{$\begin{array}{l}\text { Assembly } \\
\text { and test }\end{array}$} & Assembly requires highly skilled staff - 'a black art' & 1 & 2 & 3 & 4 & Simple assembly with minimum training \\
\hline & Extensive testing required & 1 & 2 & 3 & 4 & Designed to minimise the need for testing in production \\
\hline & Too many fasteners - different types and sizes & 1 & 2 & 3 & 4 & Few fasteners - all clearly justified \\
\hline & Specialist assembly and test equipment needed & 1 & 2 & 3 & 4 & Minimum tooling needed with few (if any) specialist tools \\
\hline & $\begin{array}{r}\text { Assembly from many directions, with poor access for } \\
\text { inserting and fixing }\end{array}$ & 1 & 2 & 3 & 4 & $\begin{array}{l}\text { Simple assembly from a single direction (above preferably) } \\
\text { with open access }\end{array}$ \\
\hline & $\begin{array}{l}\text { Several 'tricky to handle' components (large, small, } \\
\text { tangle, flexible, nesting etc.) }\end{array}$ & 1 & 2 & 3 & 4 & No component handling difficulties \\
\hline & A confusing mess of wires and cables & 1 & 2 & 3 & 4 & $\begin{array}{l}\text { Cables \& wires minimised - and simply organised when } \\
\text { needed }\end{array}$ \\
\hline & Lots of setting \& adjustment needed & 1 & 2 & 3 & 4 & Designed to minimise the need for setting \& adjustment \\
\hline \multirow[t]{2}{*}{$\begin{array}{l}\text { Platform } \\
\text { strategy }\end{array}$} & $\begin{array}{l}\text { No product platform strategy, with each product using } \\
\text { different modules, components and production methods }\end{array}$ & 1 & 2 & 3 & 4 & $\begin{array}{l}\text { Defined product platforms with a high level of module, } \\
\text { component and process reuse across products }\end{array}$ \\
\hline & Overall poor producibility & 1 & 2 & 3 & 4 & Overall good producibility \\
\hline
\end{tabular}

Novelty \& differentiation ...

\begin{tabular}{|c|c|c|c|c|c|c|}
\hline \multirow{2}{*}{$\begin{array}{c}\text { Issue } \\
\text { Core benefits }\end{array}$} & \multirow{2}{*}{$\begin{array}{r}\text { Poor performance } \\
\text { No clear differentiation - generic product with standard } \\
\text { features }\end{array}$} & \multicolumn{4}{|c|}{ Score (1-4) } & \multirow{2}{*}{$\begin{array}{l}\text { Great performance } \\
\text { Clearly differentiated offering - unique benefits to owning or } \\
\text { using }\end{array}$} \\
\hline & & 1 & 2 & 3 & 4 & \\
\hline $\begin{array}{l}\text { Functions \& } \\
\text { features }\end{array}$ & "Me-too" product - standard features at a standard price & 1 & 2 & 3 & 4 & $\begin{array}{l}\text { Radical solution that addresses the 'problem' in new and } \\
\text { interesting ways }\end{array}$ \\
\hline Technology & Yesterday's technology - not a differentiator & 1 & 2 & 3 & 4 & $\begin{array}{l}\text { Novel / disruptive technology - innovative \& will change the } \\
\text { market - a key differentiator }\end{array}$ \\
\hline $\begin{array}{l}\text { Technical } \\
\text { quality }\end{array}$ & $\begin{array}{l}\text { Engineering quality offers no differentiation - } \\
\text { robustness, reliability or serviceability etc. }\end{array}$ & 1 & 2 & 3 & 4 & $\begin{array}{l}\text { Engineering quality a key differentiator - robustness, } \\
\text { reliability or serviceability etc. }\end{array}$ \\
\hline Aesthetics & Visually average - not a differentiator & 1 & 2 & 3 & 4 & Novel aesthetics - a key differentiator \\
\hline Usability & $\begin{array}{r}\text { Standard user interface and controls - not a } \\
\text { differentiator }\end{array}$ & 1 & 2 & 3 & 4 & Highly usable \& inclusive - a key differentiator \\
\hline Brand & Low brand 'equity' - not a differentiator & 1 & 2 & 3 & 4 & Strong \& original brand presence - a key differentiator \\
\hline $\begin{array}{l}\text { After sales } \\
\text { support }\end{array}$ & $\begin{array}{r}\text { Training, service, support and maintenance not a } \\
\text { differentiator }\end{array}$ & 1 & 2 & 3 & 4 & $\begin{array}{l}\text { After sales support offers unique differentiation (service, } \\
\text { maintenance, training etc) }\end{array}$ \\
\hline $\begin{array}{l}\text { Finance \& } \\
\text { warranty }\end{array}$ & No differentiation through financing or warranties & 1 & 2 & 3 & 4 & $\begin{array}{l}\text { Novel finance or warranty arrangements provide clear } \\
\text { differentiation }\end{array}$ \\
\hline Delivery & No differentiation through delivery & 1 & 2 & 3 & 4 & Delivery capability offers real differentiation \\
\hline \multirow{3}{*}{$\begin{array}{c}\text { Other } \\
\text { qualities } \\
\text { (name them) }\end{array}$} & No differentiation or novelty & 1 & 2 & 3 & 4 & Novel approach / a key differentiator \\
\hline & No differentiation or novelty & 1 & 2 & 3 & 4 & Novel approach / a key differentiator \\
\hline & No differentiation or novelty & 1 & 2 & 3 & 4 & Novel approach / a key differentiator \\
\hline & Overall poor novelty \& differentiation & 1 & 2 & 3 & 4 & Overall good novelty \&differentiation \\
\hline
\end{tabular}




\section{Author Information}

\section{Dr James MOULTRIE}

Institute for Manufacturing, University of Cambridge, Mill Lane, Cambridge, CB2 1RX, UK,

$$
\text { jm329@eng.cam.ac.uk }
$$

James Moultrie research interests are in the area of product design, new product development inbound-marketing and design management. He is a Chartered Mechanical Engineer (IMechE) and has experience as a product marketing manager, project manager and senior engineer in the precision instruments sector. In 2000 he was awarded a 'Scientific and Technical Academy Award' and an Emmy for work on a range of lenses for professional cinematography.

\section{Professor P John CLARKSON}

Head of the Engineering Design Centre, Department of Engineering, University of Cambridge John Clarkson's research interests are in the general area of engineering design, particularly the development of design methodologies to address specific design issues, for example, complex systems design, medical equipment design, inclusive design and the use of knowledge-based systems in design. As well as publishing over 250 papers in the past ten years he has written a number of books on medical equipment design and inclusive design. Prior to his academic career, he had a wide range of product development experience, with a focus on medical equipment design and training simulation for the Ministry of Defence.

\section{David PROBERT}

Head of the Centre for Technology Management, Institute for Manufacturing, Department of Engineering, University of Cambridge

David Probert is a founding member and Head of the Centre for Technology Management within the Institute for Manufacturing at the University of Cambridge. His research interests span the field of technology management from technology acquisition to exploitation. He has significant industrial experience covering a wide range of industrial engineering and management disciplines in the UK and overseas. 